\title{
CAPITAL FLOWS DI INDONESIA: PERILAKU, PERAN, DAN OPTIMALITAS PENGGUNAANNYA BAGI PEREKONOMIAN
}

\author{
Fiskara Indawan, Sri Fitriani, Meily Ika Permata dan Indriani Karlina'
}

\begin{abstract}
Berlimpahnya likuiditas global paska krisis global mengakibatkan membanjirnya aliran modal internasional ke pasar Surat Utang Negara (SUN). Selain bermanfaat, aliran modal asing tersebut, berpotensi menimbul risiko pembalikan aliran modal asing yang dapat menimbulkan ketidakstabilan di pasar keuangan domestik. Paper ini menganalisis faktor-faktor yang mempengaruhi keputusan investasi investor asing, yang mencakup faktor risiko dan return yang berasal dari domestik (pull factor) dan global (push factor). Hasil pengujian menunjukkan push factor sangat berperan mempengaruhi perilaku investor asing di pasar SUN. Bagi investor long-term, perilaku mereka untuk menempatkan dananya di pasar SUN dipengaruhi push factor, tetapi tidak dipengaruhi secara signifikan oleh pull factor. Namun bagi investor short-term, baik pull maupun push factor, mempengaruhi keputusan investasi mereka. Selain itu hasil simulasi menunjukkan bahwa ke depan, prospek investor asing di pasar SUN masih menghadapi tantangan khususnya dari sisi volatilitas yang relatif tinggi sebagai akibat dari sensitifnya investor asing terhadap shock yang sewaktu-waktu dapat terjadi di tengah ketidakpastian kondisi pasar keuangan internasional akibat penyelesaian krisis utang di negara maju yang berlarut-larut. Dalam hal ini, Bank Indonesia dan Pemerintah perlu terus mempertahankan upaya untuk menjaga dan mengelola return dan risiko investasi di dalam negeri pada level yang lebih kompetitif dan relatif rendah dengan menjaga kekuatan dan ketangguhan perekonomian serta stabilitas keuangan domestik.
\end{abstract}

Keywords : Foreign Exchange, International Lending, Corporate Finance.

JEL Classification : F31, F34, G3

1 Peneliti Ekonomi di Grup Riset Ekonomi (BRE), Departmen Riset Ekonomi dan Kebijakan Moneter (DKM), Bank Indonesia. Pandangan dalam paper ini merupakan pandangan penulis dan tidak semata-mata merefleksikan pandangan DKM atau Bank Indonesia. E-mail: indawan@bi.go.id, sfitriani@bi.go.id, meily@bi.go.id, indriani k@bi.go.id. 


\section{PENDAHULUAN}

Berlimpahnya likuiditas global paska krisis global yang mengakibatkan membanjirnya aliran modal internasional dalam bentuk portofolio investasi ke Indonesia akan memberikan tantangan bagi pelaksanaan kebijakan moneter ${ }^{2}$. Indonesia, sebagaimana negara emerging market lainnya mempunyai tingkat pertumbuhan ekonomi yang lebih kuat dan tingkat suku bunga yang lebih tinggi, sementara di sisi lain, pada saat yang sama negara-negara maju menerapkan kebijakan moneter yang ekstra longgar dengan suku bunga yang relatif rendah. Kedua faktor tersebut sangat berperan dalam pergeseran aliran modal internasional ke emerging market yang mempunyai tingkat pengembalian yang lebih baik dan didukung oleh kinerja ekonomi dan risiko yang membaik (IMF, 2010).

Di satu sisi, masuknya modal asing tersebut menunjukkan semakin meningkatnya kepercayaan internasional terhadap fundamental ekonomi yang diperkuat dengan peningkatan rating Indonesia menjadi investment grade. Capital flow dapat meningkatkan likuiditas domestik dan dapat dimanfaatkan sebagai alternatif sumber pembiayaan investasi yang relatif lebih murah dan dapat mendorong aktivitas investasi dan mendorong perekonomian domestik.

Akan tetapi, selain bermanfaat, di sisi lain, aliran modal internasional mempunyai potensi risiko yang besar apabila tidak dikelola secara bijaksana. Masih capital inflow menyebabkan terjadinya apresiasi nilai tukar dan dapat melemahkan daya saing ekspor. Selain itu dapat menyebabkan tingginya risiko pemanasan ekonomi (overheating) pada perekonomian dan meningkatkan tekanan terhadap inflasi seiring dengan meningkatnya harga aset secara tajam serta pertumbuhan kredit dan investasi yang cenderung terlalu ekspansif. Pada saat yang sama, kondisi perekonomian global yang masih rapuh serta ketidakpastiaan pasar keuangan internasional seiring dengan krisis utang di Eropa dapat memicu terjadinya gejolak pasar keuangan internasional dan menyebabkan tingginya risiko instabilitas di pasar keuangan domestik maupun nilai tukar rupiah apabila terjadi pembalikan modal dalam waktu yang singkat (sudden reversal) terutama untuk aliran modal yang bersifat jangka pendek .

Dengan demikian, aliran modal asing tersebut diharapkan dapat dikelola dengan baik agar dapat memberikan manfaat yang optimal bagi perekonomian serta dapat diminimalkan risikonya. Untuk meminimalkan potensi risiko dalam pengelolaan aliran modal internasional tersebut, diperlukan pemahaman yang lebih baik mengenai pola perilaku capital inflow di pasar keuangan khususnya pada pasar SUN seiring dengan semakin tingginya porsi kepemilikan asing pada pasar tersebut. Analisis yang mendalam tersebut mencakup beberapa faktor yaitu faktor risiko dan return yang dapat berasal dari domestik (pull factor) maupun yang berasal dari global (push factor), yang mempengaruhi investor asing pada saat memutuskan untuk melakukan

2 Beberapa negara emerging market yang menghadapi capital inflow yang masiv telah mengambil beberapa kebijakan di luar kebijakan suku bunga dalam mengelola capital inflow seperti kebijakan makroprudensial maupun capital control (IMF, 2011). Ostry (2010) mengemukakan bahwa policy mix dalam menghadapi capital inflow tergantung dari kondisi perekonomian negara tersebut, level cadangan devisa, kualitas paraturan prudensial, penguatan nilai tukar dan persistensi capital inflow. 
pembelian dan penjualan di pasar SUN³. Analisis juga perlu difokuskan untuk mendapatkan pemahaman yang baik mengenai karakteristik investor berdasarkan horizon waktu investasi (long term maupun short term). Hasil penelitian ini diharapkan dapat memberikan rekomendasi kebijakan yang tepat dalam mengelola capital inflow khususnya di pasar keuangan.

Tujuan dari paper ini pertama adalah mengidentifikasi perilaku investor asing di pasar SUN, baik investor long-term maupun short term secara keseluruhan maupun individual khususnya transaksi net (pembelian dikurangi penjualan) di pasar sekunder SUN. Analisis identifikasi perilaku tersebut mencakup faktor-faktor yang mempengaruhi motivasi investor yaitu faktor return and faktor risiko, baik itu yang bersumber dari domestik (pull factors) maupun yang berasal dari global (push factors). Kedua, melakukan simulasi terhadap prospek investor asing di pasar SUN dengan menggunakan hasil uji estimasi, dan ketiga, merekomendasikan aspek-aspek yang perlu diperhatikan dalam pengelolaan aliran modal internasional berdasarkan temuan dari kedua tujuan penelitian ini.

\section{TEORI}

\subsection{Modern Portfolio Theory (MPT)}

Modern Portfolio Theory (MPT) atau Portfolio Theory adalah formulasi matematis dari konsep diversifikasi dalam investasi, dengan tujuan untuk memilih kumpulan aset investasi yang memberikan komposisi paling efisien baik dari sisi return maupun risiko. MPT merupakan suatu teori keuangan yang mencoba untuk menetapkan komposisi atau proporsi dari berbagai pilihan aset, sehingga dapat memaksimalkan expectedreturn portofolio untuk suatu tingkat risiko tertentu, atau sebaliknya meminimalkan risiko untuk suatu tingkat expectedreturn tertentu. Teori ini pertama kali diperkenalkan oleh Harry Markowitz (1952) dan dikembangkan oleh James Tobin (1958) dengan menambahkan aset yang bersifat risk-free ke dalam analisis.

Jika investor khususnya investor asing memiliki dua pilihan portofolio investasi yang berisiko yaitu investasi di pasar keuangan Indonesia yang memiliki return $R_{D}$ dan variance $\sigma_{D}^{2}$ dan di pasar keuangan internasional dengan return $R_{F}$ dan variance $\sigma_{F}^{2}$. Investor dapat menanamkan dananya dengan proporsi sebesar $\omega_{p}$ untuk aset di pasar keuangan Indonesia dan sebesar $1-\omega_{P}$ untuk aset di pasar keuangan internasional, maka expected return portofolio dan risiko portofolio tersebut adalah:

$$
\begin{aligned}
& R_{P}=\omega_{P} R_{D}+\left(1-\omega_{P}\right) R_{F} \\
& \sigma_{P}^{2}=E\left(R_{P}-E R_{P}\right)^{2}=\omega_{P}^{2} \sigma_{D}^{2}+2 \omega_{P}\left(1-\omega_{P}\right) \rho \sigma_{D} \sigma_{F}+\left(1-\omega_{P}\right)^{2} \sigma_{F}^{2}
\end{aligned}
$$

dimana $\sigma_{F}$ adalah standard deviasi $R_{D}$ dan $R_{F}$ dan adalah korelasi antara $R_{D}$ dan $R_{F}$.

3 Analisis menggunakan data berfrekuensi tinggi (data harian). 
Dalam teori portofolio yang menggunakan model mean-variance, investor akan memilih portofolio investasi yang efisien (efficient portfolio) yaitu yang memiliki return yang tinggi dengan risiko yang rendah. Dalam grafik 1, kombinasi seluruh portofolio yang efisien berada dalam kurva BB dimana risiko investasi $\sigma_{P}^{2}$ menjadi kecil pada setiap return investasi $R p$.

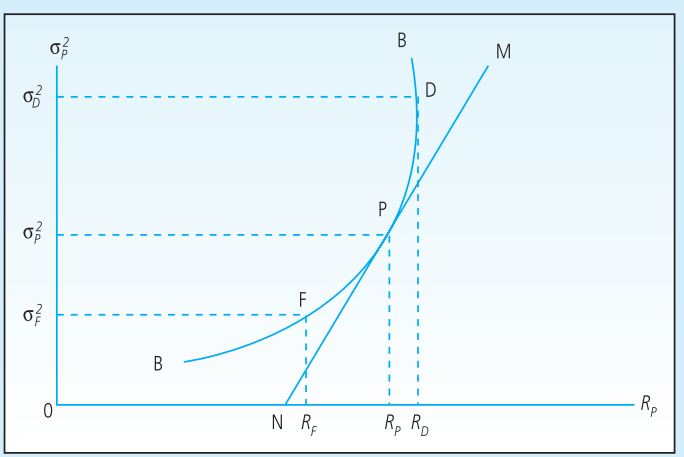

Grafik 1.

Efficient Portfolio

Untuk mengetahui alokasi portofolio yang optimal antara investasi dalam negeri dan luar negeri maka digunakan capital market line MN yang merupakan kombinasi return dan risiko dari aset yang berisiko dan tidak berisiko. Slope garis ini dalam ekulibrium akan menyentuh kurva BB pada titik $\mathrm{P}$, yang merupakan kombinasi portofolio yang memiliki return $R_{P}$ dan tingkat risiko $\sigma_{P}^{2}$. Apabila investor ingin memperoleh return yang lebih besar maka ia harus menambah portofolio investasinya pada aset yang berisiko serta yang memiliki risiko yang lebih besar pula sehingga menuju titik $\mathrm{M}$. Sebaliknya investor akan memperoleh return yang lebih kecil apabila memegang investasi yang memiliki risiko lebih kecil sehingga bergerak menuju titik $\mathrm{N}$.

Jumlah investasi yang optimal $\omega_{P}^{*}$ diperoleh dari substitusi persamaan (1) dan (2) ke dalam slope $\sigma_{P}^{2} /(R p-N)$ dan slope $\left(\partial \sigma_{P}^{2} / \partial \omega_{\mathrm{p}}\right) /\left(\partial R_{P} / \partial \omega_{\mathrm{p}}\right)$ seperti yang digunakan oleh Miller (1971), sehingga diperoleh:

$$
\omega_{P}^{*}=\frac{\left(\sigma_{F}^{2} R+K\right)}{(L+K R)}=f\left(R, \sigma_{D}^{2}, \sigma_{F}^{2}\right)
$$

Dimana

$$
\begin{array}{r}
R=\frac{\left(R_{D}-R_{F}\right)}{\left(R_{P}-N\right)}(3 \mathrm{a}) \\
K=\sigma_{F}^{2}-\rho \sigma_{D} \sigma_{F} \\
L=\sigma_{D}^{2}+\sigma_{F}^{2}-2 \rho \sigma_{D} \sigma_{F}
\end{array}
$$




\subsection{Investor long-term vs short-term}

Investor jangka panjang (longterm) dan jangka pendek (short-term) memiliki perbedaan dalam hal jangka waktu investasi. Dengan menggunakan teori portofolio dengan analisis mean-variance, Campbell dan Viceira (2001) mengemukakan bahwa investor jangka pendek dihadapkan pada masalah maksimalisasi kekayaan (wealth) dalam satu periode

$$
\max E_{t} W_{t+1}^{1-\gamma} /(1-\gamma)
$$

Dimana

$$
\log E_{t} W_{t+1}^{1-\gamma}=(1-\gamma) E_{t} w_{t+1}+\frac{1}{2}(1-\gamma)^{2} \sigma_{w t}^{2}
$$

subject to

$$
\begin{aligned}
& W_{t+1}=\left(1+R_{P, t+1}\right) W_{t} \\
& R_{P, t+1}=\alpha_{t} R_{t+1}+\left(1-\alpha_{t}\right) R_{R F, t+1}
\end{aligned}
$$

Dimana $R_{p, t+1}$ adalah return portofolio, $R_{t+1}$ adalah returnrisky assets, $R_{R F, t+1}$ adalah returnrisk-free assets, $\alpha_{t}$ adalah share portofolio yang ditempatkan pada risky assets, dan $\gamma$ adalah koefisien relatif risk aversion.

Selanjutnya substitusi persamaan (6) ke (5) dan selanjutnya (4b) dan (4a) sehingga diperoleh maksimalisasi problem bagi investor jangka pendek sbb:

$\max \log E_{t}\left(1+R_{P, t+1}\right)-\frac{1}{2} \gamma \sigma_{p t}^{2}$

Dari persamaan (7) diperoleh bahwa investor jangka pendek akan mencapai maksimum wealth dengan cara memaksimumkan return portofolionya dan meminimalkan risiko (variance) portofolio. Optimal return dan variance portofolio adalah

$$
\begin{aligned}
& r_{P, t+1}-r_{r f, t+1}=\alpha_{t}\left(r_{t+1}-r_{r f, t+1}\right)+\frac{1}{2} \alpha_{t}\left(1-\alpha_{t}\right) \sigma_{t}^{2} \\
& \sigma_{p, t}^{2}=\alpha_{t}^{2} \sigma_{t}^{2}
\end{aligned}
$$

Sementara itu investor jangka panjang menghadapi masalah wealth pada periode $\mathrm{K}$ ke depan sehingga budget constraint-nya adalah

$$
W_{t+K}=\left(1+R_{P K, t+K}\right) W_{t}
$$

Maksimisasi problem pada investor jangka panjang menjadi

$$
\max \log E_{t}\left(1+R_{P, t+K}\right)-\frac{1}{2} \gamma \sigma_{p t+K}^{2}
$$

Sehingga optimal return dan variance portofolio adalah

$$
\begin{aligned}
& K\left(r_{P, t+1}-r_{r f, t+1}\right)=\alpha_{t} K\left(r_{t+1}-r_{r f, t+1}\right)+\frac{1}{2} \alpha_{t}\left(1-\alpha_{t}\right) K \sigma_{t}^{2} \\
& \sigma_{p, t+K}^{2}=\alpha_{t}^{2} K \sigma_{t}^{2}
\end{aligned}
$$


Dari perbandingan antara persamaan (8) dan (9) dengan (12) dan (13) terlihat bahwa return dan variance portofolio investor jangka pendek masih optimal bagi investor jangka panjang. Mean dan variance investor jangka pendek adalah sama dengan investor jangka panjang yang dikalikan dengan faktor periode $\mathrm{K}$.

\subsection{Faktor Penentu Pergerakan Modal}

Masuknya aliran dana (capital inflow) ke negara berkembang disebabkan oleh beberapa faktor. Tingginya tingkat integrasi keuangan seiring dengan pesatnya perkembangan teknologi terutama teknologi informasi dan komunikasi, memainkan peran yang besar dalam mempercepat peningkatan mobilitas capital flow. Selain itu, pengembangan infrastruktur pasar modal yang disertai dengan liberalisasi pasar modal seperti penghapusan hambatan repatriasi, pengurangan hambatan pastisipasi dan kepemilikan pihak asing, juga berkontribusi terhadap perluasan capital flow ke pasar negara berkembang.

Terdapat dua faktor penentu utama untuk capital inflow (Agenor, 2004; Calvo et al, 1994):

1. Internal atau pull factors, yang terkait dengan kebijakan dalam negeri, seperti tingkinya tingkat produktivitas dan tingkat pertumbuhan, kuatnya fundamental makroekonomi, stabilisasi makroekonomi, reformasi yang bersifat struktural (contohnya liberasisasi kapital dan penurunan defisit fiskal), yang biasanya akan terkompensasi dan terefleksi dengan peningkatan rating suatu negara.

2. External atau push factors seperti (1) tingkat suku bunga dunia yang rendah, terutama di AS dan beberapa negara maju lainnya, yang akan menyebabkan terjadinya penurunan premi risiko, sementara di sisi lain emerging markets memberikan yield yang lebih tinggi (2) resesi atau perlambatan tingkat pertumbuhan di negara maju akan menghasilkan tingkat return yang rendah dan mengurangi peluang keuntungan (profit opportunity) sehingga akan menyebabkan terjadinya perpindahan capital dari negara maju ke emerging markets.

Berdasarkan jenis dan risikonya, capital flows dapat dikategorikan sebagai berikut :

Larrain et al. (1997) menemukan bahwa long term flows cenderung dipengaruhi oleh fundamental ekonomi, sementara short term flows lebih banyak dipengaruhi oleh interest rate differential. Agung et al. (2011) dengan menggunakan data Indonesia dan model VAR, menemukan bahwa capital inflows ke Indonesia terutama disebabkan oleh "push factor", terutama akibat kebijakan moneter ekstra longgar yang diterapkan oleh negara-negara maju. Selain itu, ditemukan juga bahwa inflows tersebut sangat rentan terhadap risiko pembalikan (reversal). 


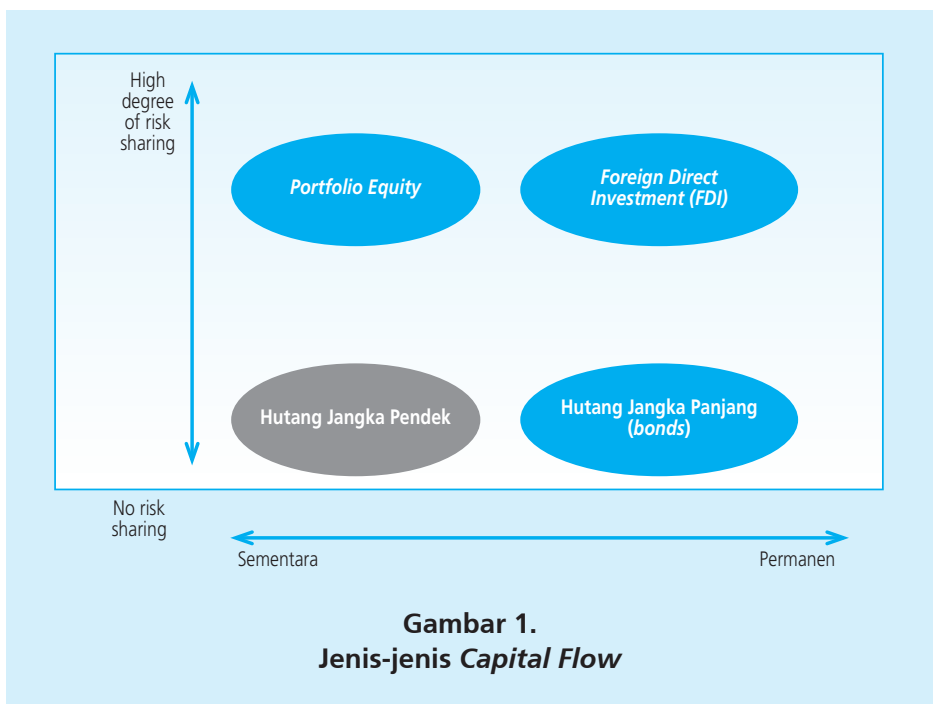

\subsection{Landasan Empiris}

Beberapa penelitian telah menganalisis faktor-faktor yang menyebabkan mengalirnya arus modal asing masuk ke negara-negara berkembang. Terdapat beberapa penelitian yang secara khusus menggunakan VAR dalam menganalisis capital flows di negara emerging seperti Ying dan Kim (2001), Vita dan Kyaw (2007), Goldfajn dan Minella (2005), dan Culha (2006). Secara umum Culha (2006) dan Fratzscher (2011) menyatakan bahwa faktor dari dalam negeri (pull factors) merupakan faktor penting dalam menarik capital flows di negara emerging. Sedangkan Forbes dan Warnock (2011) menyatakan bahwa faktor dari luar negeri (push factors) menjadi faktor penggerak aliran modal ke negara emerging.

Agung et al (2011) dengan menggunakan metode OLS dengan data bulanan dari Januari 2004 - Desember 2010 meneliti faktor-faktor yang mempengaruhi capital flows di pasar saham, SBI dan SUN. Hasil yang diperoleh yaitu capital flows dipengaruhi secara positif oleh dua pull factors yaitu pertumbuhan ekonomi dalam negeri (indeks produksi) dan perubahan suku bunga dalam negeri serta 3 push factors yaitu tingkat risiko global (EMBIG), ekses likuiditas global (jumlah uang beredar di AS) dan perubahan suku bunga AS. Sementara itu capital flows dipengaruhi secara negatif oleh pertumbuhan ekonomi AS. Selanjutnya untuk meneliti pengaruh capital flows terhadap variabel makroekonomi maka analisis menggunakan metode VAR dan data kuartalan pada periode 1994 - 2010. Hasil yang diperoleh yaitu capital flows memberikan pengaruh positif pada cadangan devisa, uang beredar dan IHSG, serta pengaruh negatif pada nilai tukar riil (apresiasi).

Nugroho (2010) meneliti faktor-faktor yang mempengaruhi capital flows yang diproksi dari transaksi valas oleh pihak asing dengan bank domestik dari LHBU. Analisis yang menggunakan metode OLS dan data bulanan dari Januari 2002 - Maret 2010 menemukan bahwa capital flows 
dipengaruhi secara positif oleh 2 faktor yaitu spread antara suku bunga JIBOR dalam negeri dengan suku bunga komposit LIBOR dan pertumbuhan ekonomi AS (US consumer confidence dan US indeks produksi), dan dipengaruhi secara negatif oleh ekspektasi nilai tukar (depresiasi menyebabkan capital outflow).

Cadarajat (2008) dengan menggunakan metode ARDL dan data kuartalan dari tahun 1985-2007 mengemukakan bahwa capital flows yang diproksi dari FDI, FPI dan other investment berpengaruh positif terhadap current account, domestic economic growth dan IHSG dan berpengaruh negatif dari country risk dan real interest rate.

Di pasar keuangan (saham dan SUN) terdapat hubungan positif antara volatilitas harga dengan volume perdagangan. Semakin tinggi volume perdagangan maka akan semakin tinggi pula volatilitas harga di pasar. Karpoff (1987) menyatakan bahwa hubungan volatilitas harga dengan volume perdagangan dapat memberikan gambaran yang lebih jelas mengenai aliran dan diseminasi informasi yang terjadi di pasar serta struktur dan ukuran pasar. Hubungan yang positif antara kedua variabel mengindikasikan bahwa pasar menjadi lebih transparan karena tersedia banyak investor yang dapat memperoleh berbagai informasi mengenai kondisi pasar maupun fundamental dari berbagai sumber.

\section{METODOLOGI}

\subsection{Teknik Estimasi}

Dalam series data keuangan, yang biasanya merupakan data high frequencies yang bersifat harian ataupun mingguan, seringkali ditemukan volatility clustering, dimana terdapat periode dengan tingkat volatilitas yang tinggi (high volatility) namun sebaliknya pada waktu yang berbeda terdapat periode dengan tingkat volatilitas yang rendah (low volatility). Pada periode high volatility, suatu shock yang besar (residual) cenderung akan diikuti oleh shock yang besar pula, demikian pula sebaliknya, pada periode low volatility, shock yang kecil akan diikuti dengan shock yang kecil pula.

Model regresi linear biasa mengedepankan asumsi volatilitas yang stabil (homoscedasticity). Pada kasus di atas, dimana syarat homoscedasticity tidak dapat dipenuhi, pemodelan dapat dilakukan dengan membolehkan variance dari $\varepsilon_{\mathrm{t}}$ dipengaruhi oleh error term periode sebelumnya. Pemodelan dan forecast terhadap volatilitas memberikan beberapa keuntungan antara lain estimator akan lebih efisien jika kendala heteroscedasticity dapat diatasi. Selain itu, karena forecast confidence interval dapat bervariasi antar waktu, pemodelan variance dari error term akan membantu memberikan interval yang lebih akurat.

Engle (1982) memperkenalkan konsep Autoregressive Conditional Heteroscedasticity (ARCH). Dalam model ini, variance dari error term pada periode t dipengaruhi oleh kuadrat dari error term (volatilitas) beberapa periode sebelumnya. 


$$
\sigma_{t}^{2} \equiv E\left\{\varepsilon_{t}^{2} \mid I_{t-1}\right\}=\omega+\alpha \varepsilon_{t-1}^{2}
$$

Dengan $\omega \geq 0$ dan $\alpha \geq 0$. Model diatas merupakan $\mathrm{ARCH}(1)$, dengan $l_{t-1}$ merupakan kumpulan informasi yang mencakup $\varepsilon_{t-1}^{2}$ dan semua informasi terdahulu. Model $A R C H(1)$ menyatakan bahwa ketika shock yang cukup besar terjadi di periode $t$ - 1 , maka kemungkinan besar $\varepsilon_{t}^{2}$ akan besar dan $\sigma_{t}^{2}$ akan cenderung besar pula. Dengan kata lain, terdapat hubungan korelasi antara $\varepsilon_{t}^{2}$ dengan $\varepsilon_{t-1}^{2}$. Unconditional variance dari $\varepsilon_{t}^{2}$ adalah :

$$
\sigma_{t}^{2} \equiv E\left\{\varepsilon_{t}^{2}\right\}=\omega+\alpha E\left\{\varepsilon_{t-1}^{2}\right\}
$$

Persamaan di atas mempunyai solusi yang stasioner yaitu : $\sigma_{t}^{2}=\frac{\omega}{1-a}$, karena $0 \leq \alpha \leq$ Perlu diingat bahwa unconditional variance tidak tergantung pada $t$.

Model $\mathrm{ARCH}(1)$ dapat diperluas menjadi $\mathrm{ARCH}(\mathrm{p})$ dan dapat dinyatakan sebagai berikut:

$$
\sigma_{t}^{2}=\omega+\alpha_{1} \varepsilon_{t-1}^{2}+\alpha_{2} \varepsilon_{t-2}^{2}+\cdots+\alpha_{p} \varepsilon_{t-p}^{2}=\omega+\alpha(L) \varepsilon_{t-1}^{2}
$$

Pengembangan variasi ARCH model yang sangat bermanfaat diperkenalkan oleh Bollerslev (1986) dan kemudian dikenal dengan nama Generalized ARCH atau GARCH. Model GARCH (q,p) dapat dituliskan sebagai berikut :

$$
\sigma_{t}^{2}=\omega+\sum_{j=1}^{p} \alpha_{j} \varepsilon_{t-j}^{2}+\sum_{j=1}^{q} \beta_{j} \sigma_{t-j}^{2}
$$

Atau

$$
\sigma_{t}^{2}=\omega+\alpha(L) \varepsilon_{t-j}^{2}+\beta(L) \sigma_{t-j}^{2}
$$

Dengan $\omega \geq 0, \alpha \geq 0$ dan $\beta \geq 0$. GARCH merupakan alternatif yang lebih kompak untuk memodelkan ARCH dengan order yang tinggi. Dengan melakukan metode GARCH maka pemilihan lag dari $\varepsilon_{\mathrm{t}}$ dapat diminimalkan.

\subsection{Model Empiris}

Untuk mengetahui faktor-faktor yang mempengaruhi investor asing di pasar SUN maka dilakukan pengujian model ekonometrik untuk persamaan (24) dengan menggunakan metode GARCH.

$$
\text { Posisi Net Transaksi Investor Asing }=\left(\sum_{k=1}^{m} \propto_{k} \text { PushFactor }_{k}\right)+\left(\sum_{k=1}^{n} \beta_{k} \text { PullFactor }_{k}\right)
$$

Variabel dependen adalah posisi atau akumulasi transaksi investor asing (non-residen) long-term dan short-term. Transaksi yang dianalisis adalah posisi net inflow (transaksi pembelian dikurangi penjualan) untuk masing-masing investor long-term dan short-term secara keseluruhan maupun individu. Sementara kandidat variabel independen adalah sebagai berikut : 


\begin{tabular}{|c|c|c|c|}
\hline \multicolumn{4}{|c|}{$\begin{array}{l}\text { Tabel } 1 . \\
\text { Variabel Independen }\end{array}$} \\
\hline Factor & Variable & Data Candidate & Category \\
\hline \multirow[t]{7}{*}{ Return } & \multirow[t]{2}{*}{$\mathbf{R}_{\mathbf{D}}($ return dalam negeri) } & Yield nominal SUN 5 thn (yield5) & Pull factor \\
\hline & & $\begin{array}{l}\text { Suku bunga /yield riil SUN } 5 \text { thn (rridn) = } \\
\text { yield nominal - inflasi yoy }\end{array}$ & Pull factor \\
\hline & \multirow[t]{2}{*}{$\begin{array}{l}\mathbf{R}_{\mathbf{D}}-\mathbf{R}_{\mathbf{F}} \text { (interest rate } \\
\text { differential) }\end{array}$} & $\begin{array}{l}\text { Spread nominal = yield nominal SUN } 5 \text { thn - US T- } \\
\text { Note } 5 \text { yr (spread2) }\end{array}$ & Pull factor \\
\hline & & $\begin{array}{l}\text { Spreadriil = yield riil SUN } 5 \text { thn (rridn)- yield riil } 5 \text { thn } \\
\text { (rrus) }\end{array}$ & Pull factor \\
\hline & \multirow[t]{3}{*}{$\mathbf{R}_{\mathbf{F}}$ (return luar negeri) } & Yield nominal US T-Bills 3 month (USTB) & Push factor \\
\hline & & Yield nominal US T-Notes 5 yr (UST5) & Push factor \\
\hline & & $\begin{array}{l}\text { Suku bunga /yield riil } 5 \text { thn (rrus) = yield nominal UST } \\
5 \mathrm{yr} \text { - inflasi yoy }\end{array}$ & Push factor \\
\hline \multirow[t]{3}{*}{ Risk } & \multirow[t]{3}{*}{$\sigma_{D}^{2}$ (risiko dalam negeri) } & Suku bunga PUAB ON (puab) *) & Pull factor \\
\hline & & Nilai tukar USD/Rp (kurs) & Pull factor \\
\hline & & Credit DefaultSwap 5 thn (CDS) & Pull factor \\
\hline \multirow[t]{3}{*}{ Risk } & \multirow[t]{3}{*}{$\sigma_{F}^{2}$ (risiko luar negeri) } & VIX (vix) & Push factor \\
\hline & & TED (ted) & Push factor \\
\hline & & OIS US (oisus) & Push factor \\
\hline
\end{tabular}

Data yang digunakan adalah data harian dari tahun 2004 hingga akhir tahun 2011. Sumber data transaksi investor asing diperoleh dari transaksi SUN di pasar sekunder yang diperoleh dari sistem BI-SSSS (Bank Indonesia Scriptless Securities Settlement System). Sementara data variabel independen diperoleh dari Bloomberg.

Untuk mengetahui perilaku kelompok investor asing yang terdiri dariinvestor long term dan investor short term investor di pasar SUN, dilakukan regresi persamaan (24)dengan variabel dependen adalah net transaksi (transaksi beli - transaksi jual) dan kombinasi dari berbagai variabel independen pada Tabel 2 untuk masing-masing kelompok. Setiap persamaan mengandung 4 atau 3 variabel independen yang mewakili indikator risiko dan return global maupun risiko dan return domestik. Total persamaan yang digunakan adalah sebanyak 72 persamaan. Dari 72 persamaan tersebut, dipilih satu persamaan yang akan digunakan untuk seluruh investor asing baik secara kelompok maupun individu. Pemilihan satu persamaan tersebut dilakukan atas dasar banyaknya variabel independen yang signifikan. 


\section{HASIL DAN ANALISIS}

\subsection{Analisa Deskriptif Perkembangan Pasar Surat Utang Negara (SUN)}

Tren transaksi investor asing di Indonesia cenderung meningkat. Di tahun 2011, transaksi beli investor asing mencapai 44.7\% dari total nilai transaksi di pasar SUN Indonesia (Grafik 3). Sementara itu, jika dilihat dari net transaksi (transaksi beli dikurangi jual), maka dapat terlihat bahwa investor asing lebih banyak menjual di tahun 2006-2008, kemudian melakukan building stock di tahun 2009-2011 (Grafik 4). Dari segi posisi kepemilikan, per juni 2012, investor asing saat ini memiliki share sebesar 27.40\% (Grafik 5).

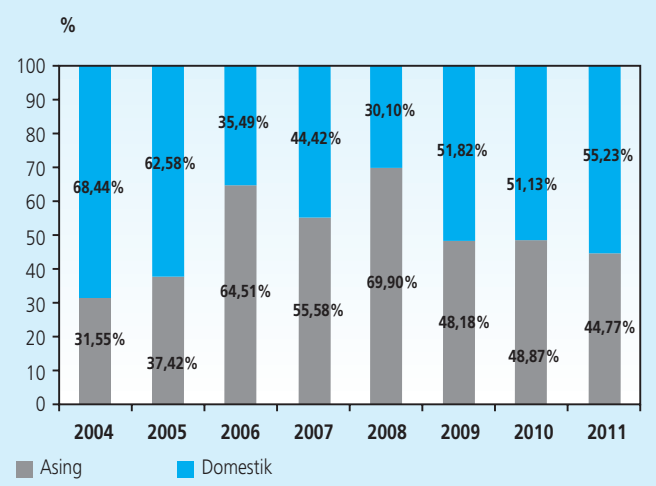

Grafik 2.

Nilai Transaksi Asing

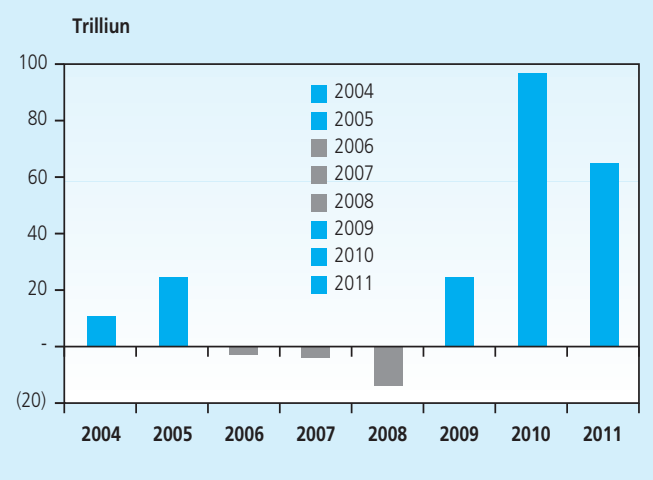

Grafik 3.

Posisi Net Beli Jual Investor Asing

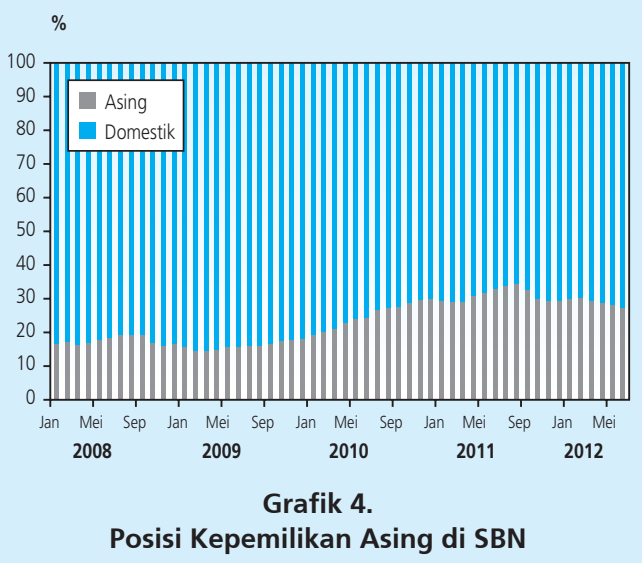

Untuk dapat mengkategorikan investor long-term maupun investor short-term maka dilakukan identifikasi dari perdagangan SUN di pasar sekunder. Pada Grafik 6 terlihat bahwa terdapat 7 investor asing terbesar yang aktif, dengan rata-rata aktivitas beli - jual $70 \%$ dari total nilai transaksi pemain asing. Sebagaimana dalam tinjauan literatur, perbedaan investor long- 
term dengan investor short-term adalah pada horison waktu investasi. Dalam paper ini investor long-term didefinisikan sebagai investor institusional asing yang mengalami peningkatan posisi SUN yang signifikan sejak tahun 2009 yang merupakan dimulainya derasnya capital inflow ke pasar SUN. Sebaliknya investor short-term adalah investor institusional asing yang tidak terdapat perubahan yang cukup signifikan pada posisi SUN pada periode yang sama. Berdasarkan definisi tersebut maka sesuai dengan tabel 4, investor yang masuk dalam kategori investor long-term adalah investor A, B dan C dan investor short-term adalah investor D, E, F dan G.

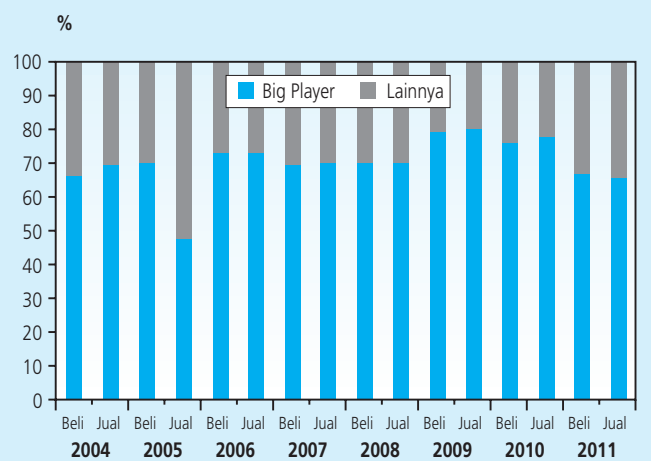

Grafik 5.

Aktivitas Jual Beli 7 Investor Asing Terbesar

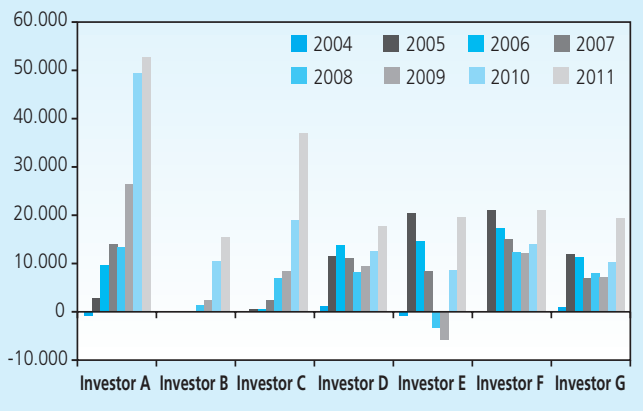

Grafik 6.

Posisi 7 Investor Asing Terbesar (Miliar Rp)

Tabel 2.

Perubahan Posisi Investor Asing Terbesar

\begin{tabular}{c|c|c|c|c} 
No & Investor & Rata-rata 2004-2008 & Rata-rata 2009-2011 & Perubahan \\
\hline 1 & A & 2.706 & 21.411 & $791,4 \%$ \\
\hline 2 & B & 1.439 & 9.442 & $656,0 \%$ \\
\hline 3 & C & 7.881 & 42.838 & $543,6 \%$ \\
\hline 4 & D & 7.901 & 12.432 & $157,4 \%$ \\
\hline 5 & E & 9.201 & 13.297 & $144,5 \%$ \\
\hline 6 & F & 13.232 & 15.756 & $119,1 \%$ \\
\hline 7 & G & 7.927 & 7.513 & $94,8 \%$
\end{tabular}


Berdasarkan kategori tersebut maka dari Tabel 4 di tahun 2011 dimana terjadi derasnya capital inflow, investor long-term dan short-term memiliki porsi yang relatif seimbang yaitu 46:34 (Grafik 9). Hal tersebut menunjukkan bahwa kedua investor memiliki pengaruh yang relatif sama di pasar SUN.

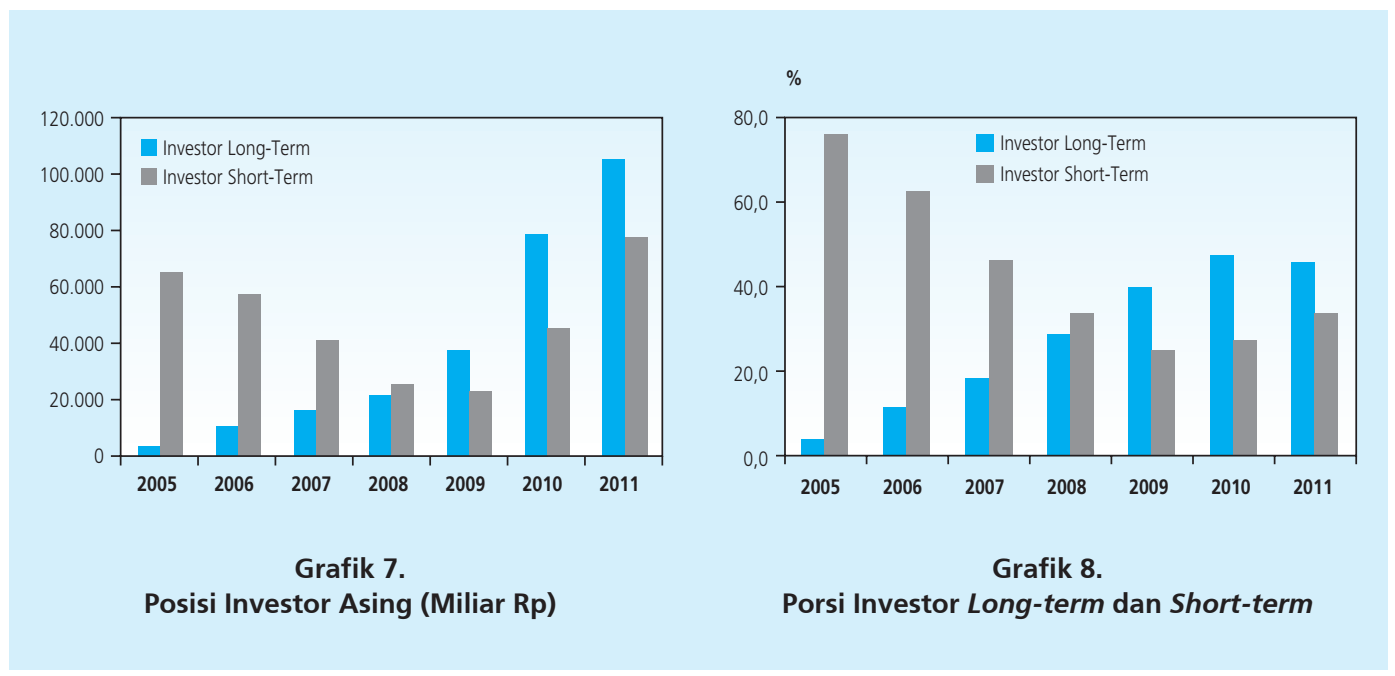

Investor long-term cenderung aktif setelah krisis keuangan global (akhir tahun 2008). Sementara itu, investor short-term telah lama aktif bertransaksi di pasar SUN Indonesia, pergerakannya pun sangat volatile dan motifnya cenderung mengharapkan capital gain (terlihat dari aktivitas beli dan jual nya yang sangat tinggi).

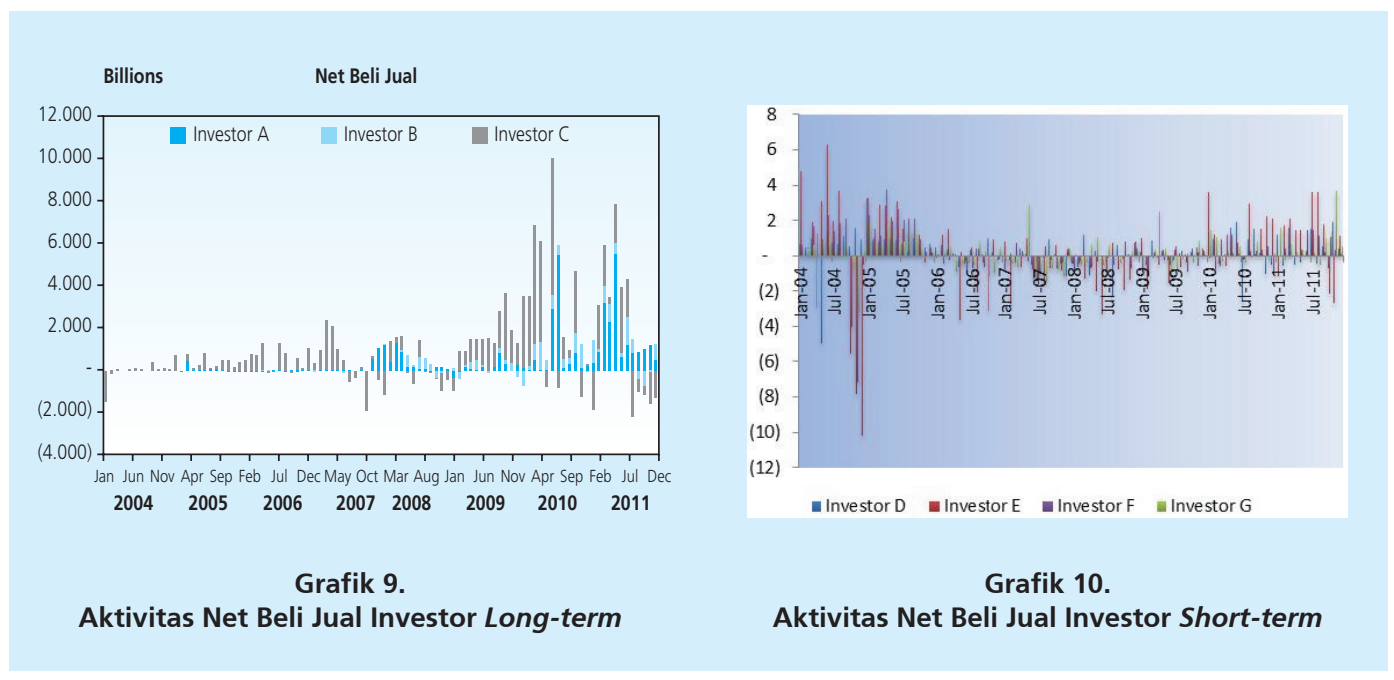




\subsection{Hasil Estimasi}

Hasil regresi terhadap kombinasi 72 persamaan dengan menggunakan GARCH (persamaan 24) diperoleh satu persamaan umum (general equation) yang dapat digunakan pada seluruh investor asing baik secara kelompok (investor long-term maupun short-term) maupun investor asing individual. Persamaan tersebut memiliki independen variabel yang terdiri dari yield SUN 5 tahun sebagai variabel return dalam negeri, yield US T Notes 5 tahunsebagai variabel return luar negeri, suku bunga PUAB ON sebagai variabel risiko dalam negeri dan indeks VIX sebagai variabel risiko luar negeri. Selanjutnya persamaan umum tersebut akan diujikan pada seluruh individual investor pada setipa kelompok investor (long-term dan short-term).

\section{Investor Jangka Panjang}

Persamaan umum yang diuji pada kelompok investor long-term menunjukkan bahwa hanya push factor (faktor global), baik profit maupun risiko yang signifikan mempengaruhi perilaku investor tersebut di pasar SUN. Hasil uji tersebut tetap konsisten pada perilaku individu kelompok investor. Dari 3 investor long term yang diuji, dua investor individu menunjukkan perilaku yang sama (Investor A dan B). Sementara itu, perilaku transaksi investor C belum dapat dijelaskan dengan baik oleh variabel yield 5 (proksi return dalam negeri), USTB (proksi return global), PUAB (proksi risiko dalam negeri) dan VIX (risiko global). Hasil regresi tersebut menunjukkan bahwa peningkatan cukup besar dari posisi investor asing long-term di pasar SUN terutama sejak dimulainya krisis keuangan global di tahun 2008 lebih didorong oleh push factor yang direpresentasikan dari rendahnya tingkat suku bunga luar negeri dan relatif tingginya tingkat risiko luar negeri. Investor asing mencari alternatif penempatan investasinya yang menawarkan suku bunga yang relatif tinggi dengan tingkat risiko yang relatif rendah.

Besarnya push factor ini menunjukkan rentannya pasar SUN terhadap risiko pembalikan aliran modal secara mendadak dalam jumlah besar apabila intensitas risiko di pasar keuangan internasional meningkat tajam. Oleh karena itu, pemerintah dan Bank Indonesia perlu terus mewaspadai dan memonitor perkembangan di pasar keuangan global, dan mempersiapkan contingency plan untuk menghadapi risiko tersebut untuk meminimalkan dampaknya terhadap kestabilan keuangan dan perekonomian domestik.

Hasil impulse response pada Grafik 11 menunjukkan bahwa shock kenaikan US T-Notes 5 tahun sebesar 100 basis poin akan menyebabkan investor long-term menurunkan posisi net transaksinya (atau dengan kata lain melakukan net jual) sekitar Rp 11 miliar pada saat itu juga $(\mathrm{t}=0)$ dengan dampak kumulatif sebesar Rp 14 milyar. Sedangkan shock kenaikan indeks VIX sebesar 100 bp menyebabkan investor long-term menjual sebesar Rp 1,7 miliar dengan dampak kumulatif sebesar Rp 2,4 milyar. Hasil impulse response secara individual (Investor A dan B) menunjukan sensitivitas yang lebih besar. Pada Grafik 12 shock kenaikan yield US T-Notes 100 bp menyebabkan investor A dan B melakukan net jual sekitar Rp 19 miliar dan kenaikan indeks VIX 100 bp menyebabkan net jual sekitar Rp 2 miliar pada saat $t=0$. 

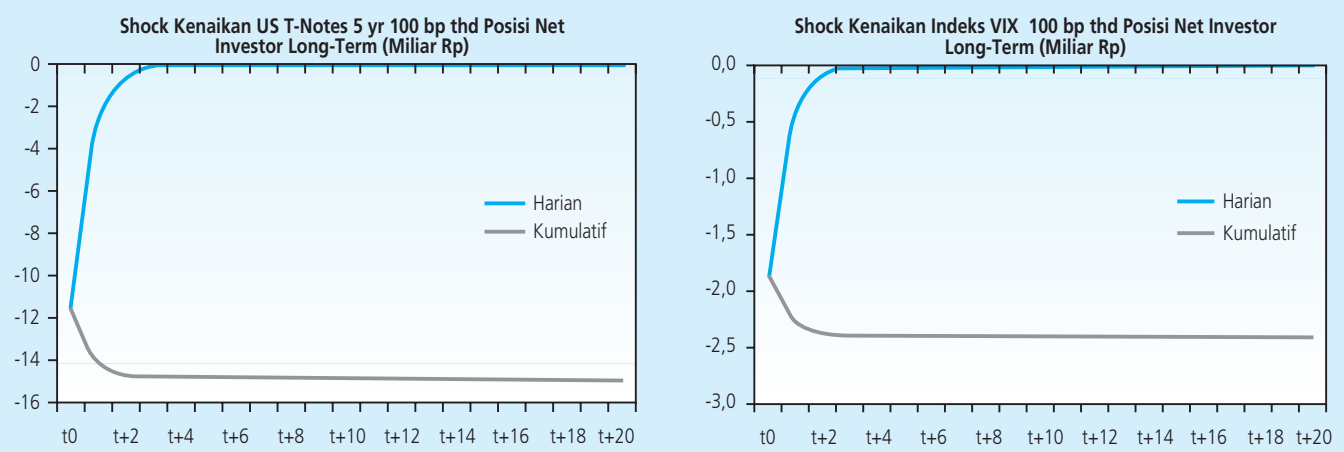

Grafik 11.

Hasil Impulse Response Function terhadap Investor Long Term (Miliar Rp)
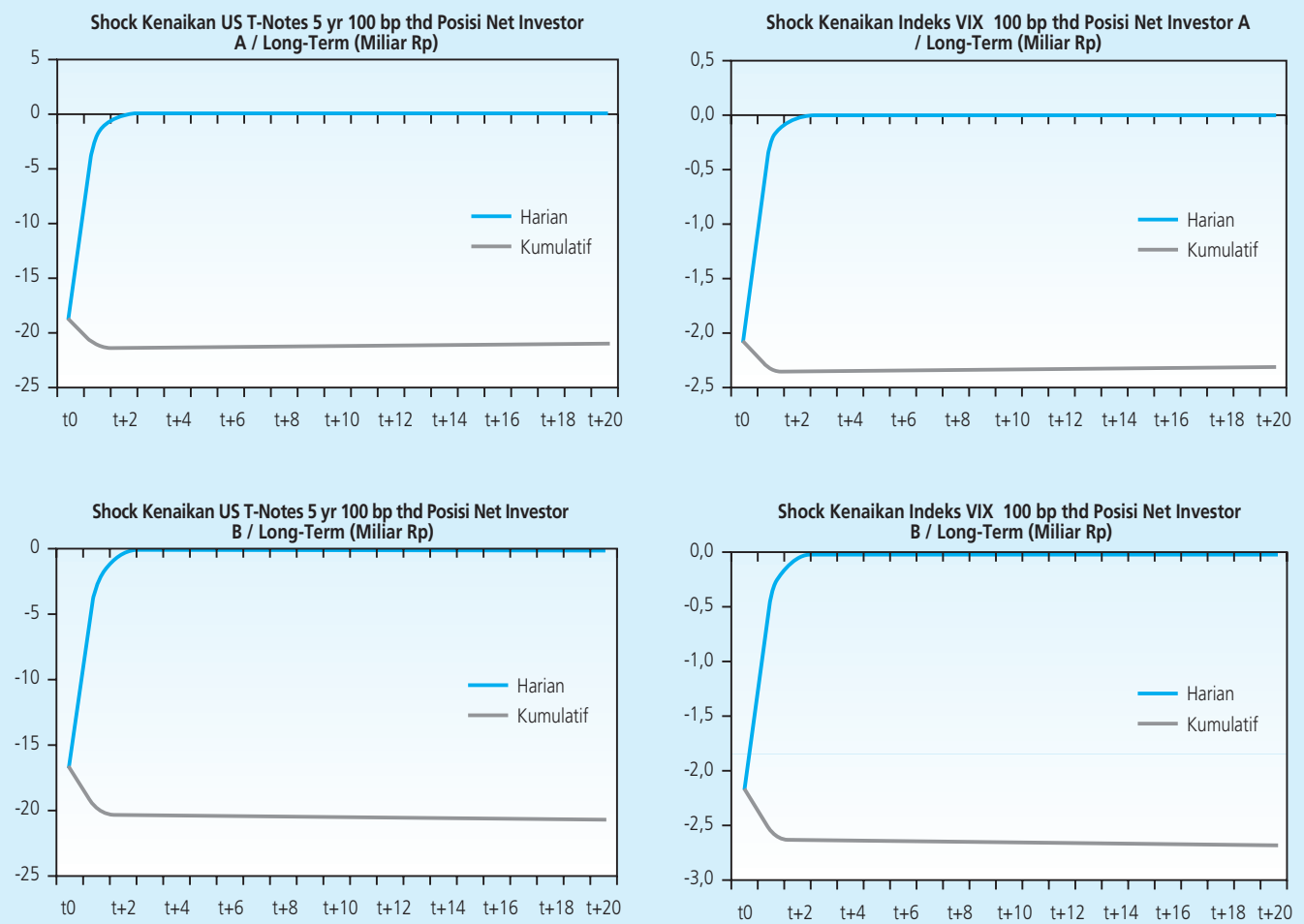

Grafik 12.

Hasil Impulse Response Function terhadap Investor A dan B /Long-Term (Miliar Rp) 


\section{Investor Jangka Pendek}

Berbeda dengan investor long-term, perilaku investor short-term dipengaruhi baik oleh push factors maupun pull factors (faktor domestik) dalam bertransaksi di pasar SUN. Hasil uji regresi ini, menunjukkan bahwa tingginya frekuensi transaksi investor jangka pendek di pasar SUN didorong lebih sensitifnya mereka terhadap setiap perubahan pulf factor maupun push factor. Kedua faktor tersebut akan mempengaruhi return yang diharapkan maupun toleransi mereka atas risiko yang dapat ditanggung. Hal ini sejalan dengan sifat transaksi investor short-term yang cenderung hanya melihat keuntungan jangka pendek melalui capital gain.

Tingginya frekuensi transaksi investor short-term yang tidak diiringi oleh meningkatnya posisi dapat menyebabkan tingginya volatilitas di pasar SUN, yang pada akhirnya dapat mempengaruhi kestabilan pasar keuangan secara keseluruhan. Oleh karena itu, mengingat transaksi investor short-term sangat volatile, makadari sisi domestik, pemerintah dan Bank Indonesia perlu memperhatikan faktor-faktor yang mempengaruhi investor short-term yaitu dengan menjaga kondisi perekonomian domestik antara lain menjaga tingkat suku bunga dalam negeri yang kompetitif serta menjaga tingkat risiko dalam negeri pada level yang cukup rendah. Sementara, untuk menghadapi risiko pembalikan aliran modal, pemerintah dan Bank Indonesia perlu terus mewaspadai risiko di pasar keuangan internasional dan mempersiapkan contingency plan.

Hasil impulse response secara individual pada Grafik 13 menunjukkan bahwa shock kenaikan Yield5 sebesar 100 basis poin akan menyebabkan investor short-term menurunkan posisi net transaksinya (atau dengan kata lain melakukan net jual) sekitar Rp 25,5 miliar pada saat itu juga ( $\mathrm{t}=0$ ) dengan dampak kumulatif sebesar Rp 31,05 milyar. Sedangkan shock kenaikan indeks UST-Notes 5 Tahun sebesar 100 bp menyebabkan investor short-term menjual sebesar Rp 80,7 miliar dengan dampak kumulatif sebesar Rp 98,3 milyar. Selanjutnya untuk shock kenaikan PUAB ON sebesar 100 bp menyebabkan investor short-term melakukan net
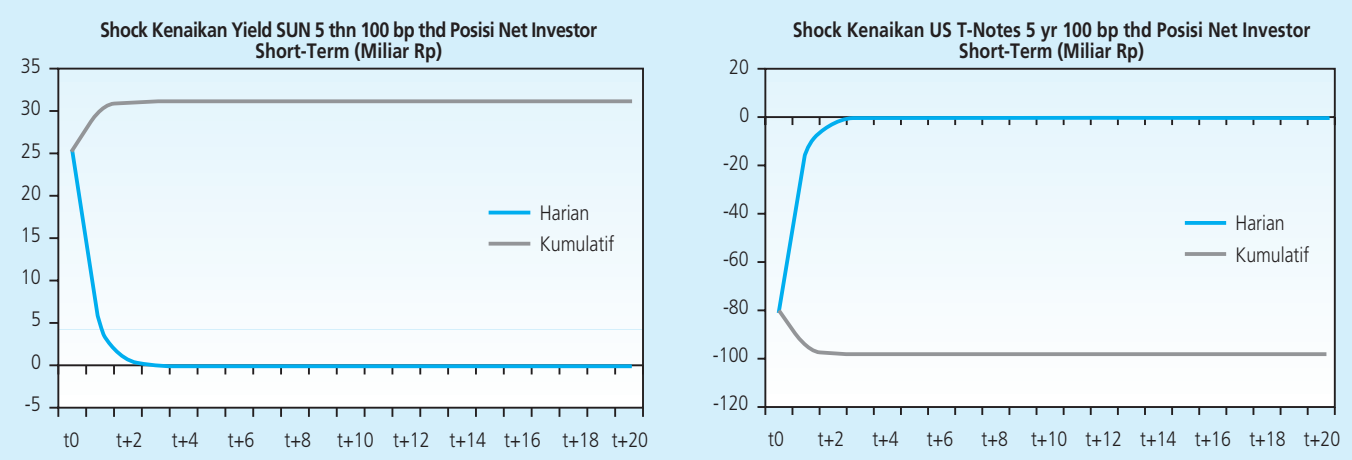

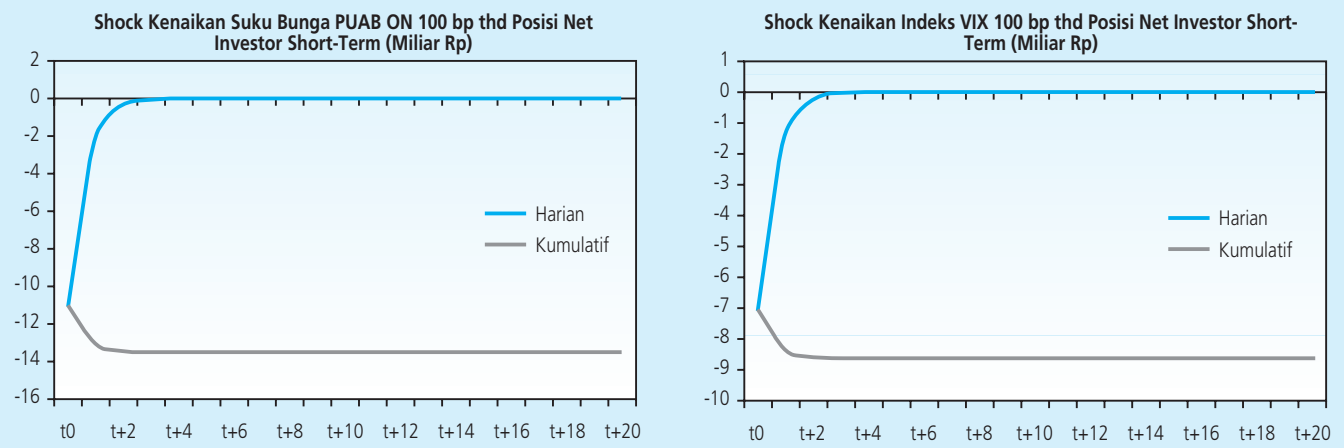

Grafik 13.

Hasil Impulse Response Function terhadap Posisi Investor Short-Term (Miliar Rp)

jual sekitar Rp 11,07 miliar dengan dampak kumulatif Rp 13,5 miliar dan kenaikan indeks VIX 100 bp menyebabkan net jual sekitar Rp 7,07 miliar pada saat $\mathrm{t}=0$ dengan dampak kumulatif sebesar Rp 8,6 miliar.

Walaupun secara umum hasil uji regresi terhadap individu investor short term menunjukkan perilaku yang serupa dengan perilaku kelompok, push factor lebih menunjukkan konsistensinya dibandingkan dengan pull factor. Variabel push factor (US T-Notes dan indeks VIX) memiliki pengaruh yang signifikan pada seluruh investor individual short-term yang diuji (Grafik 14 dan Grafik 15). Sementara itu, faktor return dalam negeri yang diproksi dengan Yield5 hanya signifikan berpengaruh terhadap 2 investor individu short term (Investor F dan G) dari 4 individu investor yang diuji. Dan, hanya satu investor (Investor F) yang secara signifikan dipengaruhi oleh risiko domestik yang diproksi dari variable PUAB.
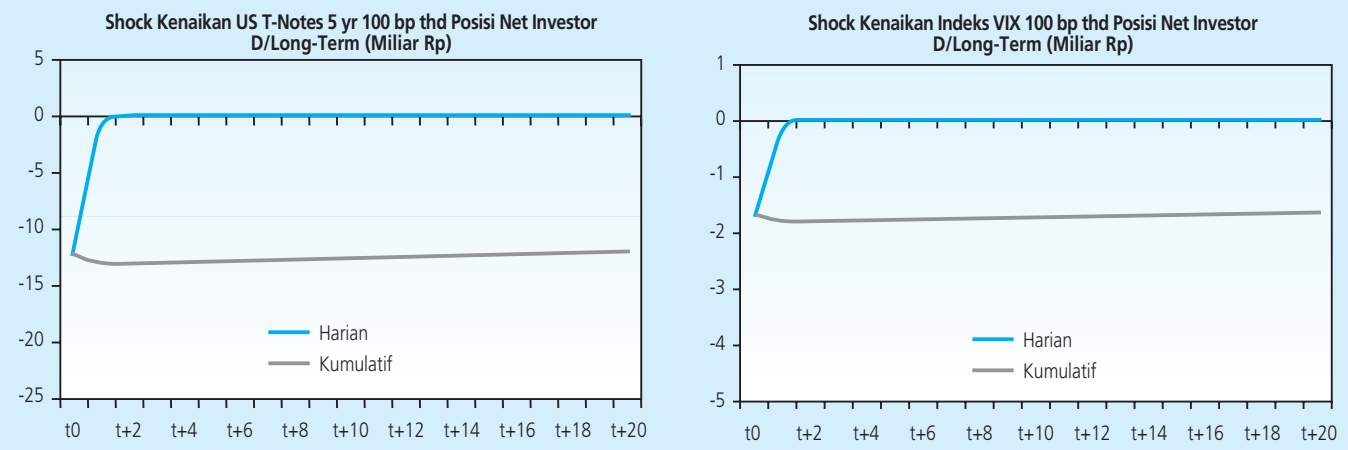

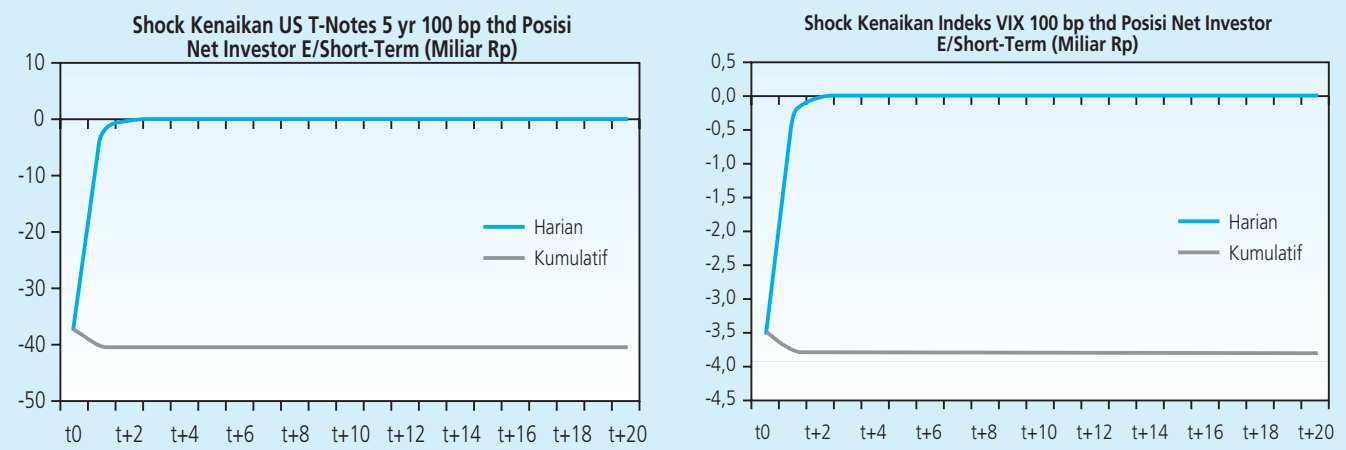

Grafik 14.

Hasil Impulse Response Function terhadap Posisi Investor Short-Term D dan E (Miliar Rp)
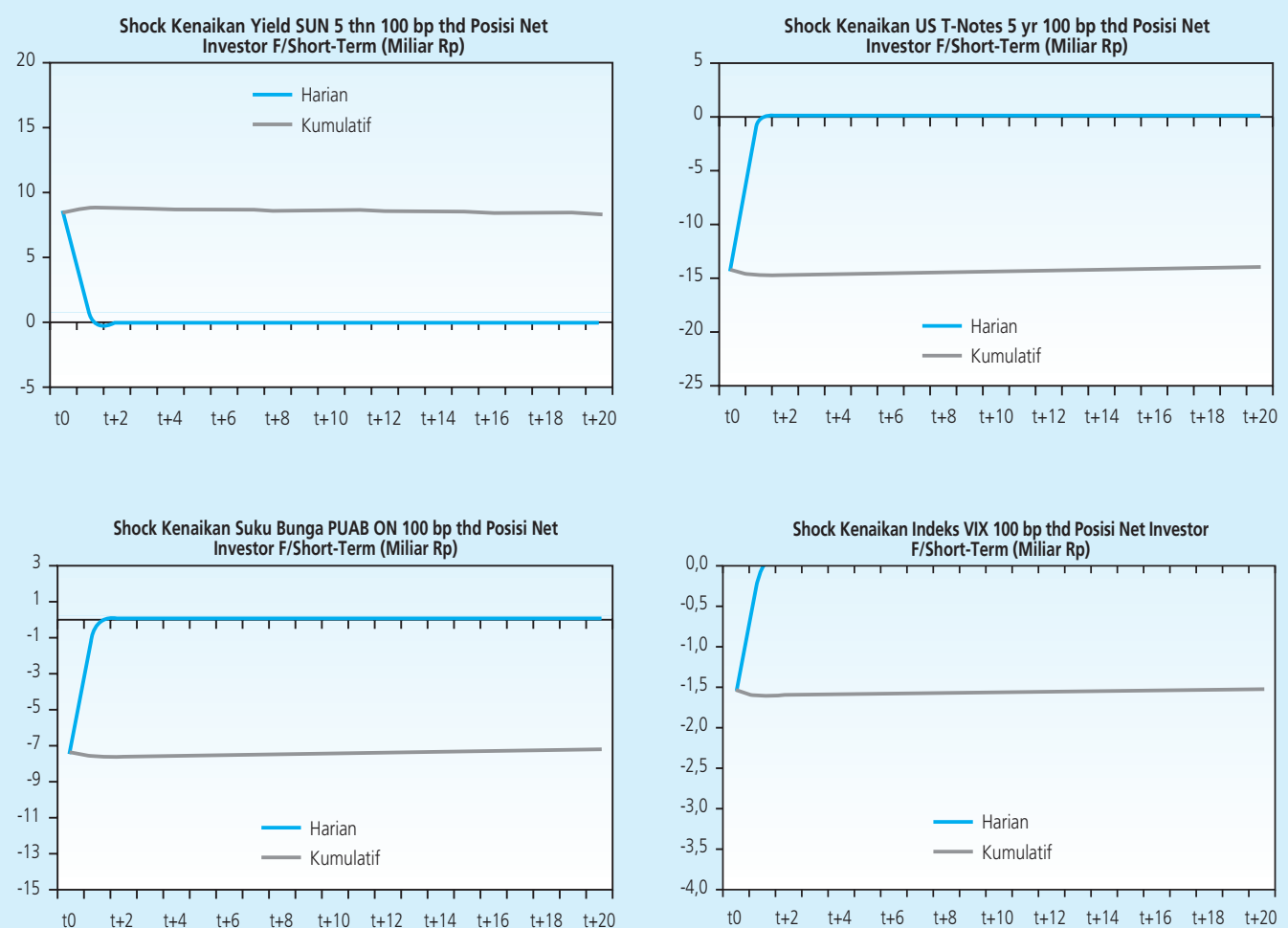

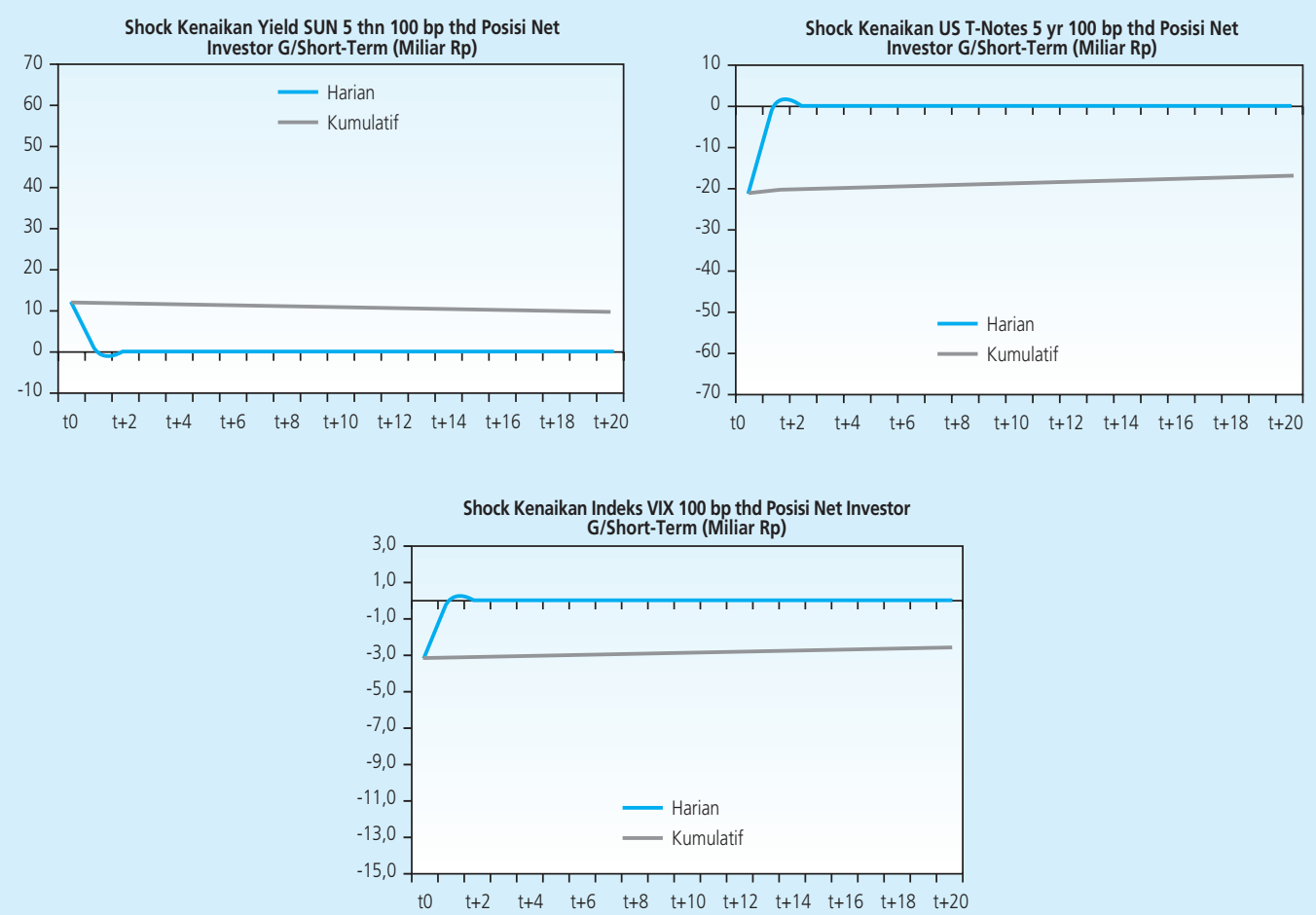

Grafik 15.

Hasil Impulse Response Function terhadap Posisi Investor Short-Term F dan G (Miliar Rp)

\section{Prospek Capital Flows}

Untuk mengetahui prospek capital flows ke depan, maka dilakukan simulasi dengan menggunakan hasil estimasi di atas terhadap investor long-term maupun short-term. Simulasi menggunakan tiga kondisi yaitu mild, moderat dan krisis $^{4}$ dengan kriteria seperti pada Tabel 3. Penentuan kriteria tersebut didasarkan atas pola historis pada setiap variabel sejak tahun 2004.

\begin{tabular}{l|l}
\multicolumn{2}{c}{ Tabel 3. } \\
\multicolumn{1}{c}{ Pola Historis Kondisi Mild, Moderat, dan Krisis } \\
\multicolumn{1}{c|}{ Kondisi } & \multicolumn{1}{c}{ Perubahan Harian } \\
\hline Mild & 1 Standard Deviasi \\
\hline Moderate & 2 Standard Deviasi \\
\hline Crisis & 4 Standard Deviasi
\end{tabular}

4 Mild dan Moderat = shock selama lima hari kerja berturut-turut (1 minggu); Crisis = shock selama 10 hari kerja berturut-turut ( 2 minggu). 
Dengan menggunakan kriteria tersebut maka dapat ditentukan shock harian yang akan digunakan oleh 4 variabel untuk melakukan simulasi, seperti pada Tabel 4.

\begin{tabular}{|c|c|c|c|}
\hline \multicolumn{4}{|c|}{$\begin{array}{c}\text { Tabel } 4 . \\
\text { Shock Harian } 4 \text { Variabel (basis poin) }\end{array}$} \\
\hline Variabel & Mild & Moderate & Crisis \\
\hline ShockYield SUN 5 Thn & 19 & 38 & 76 \\
\hline Shock US T Notes 5 Yr & 7 & 14 & $2 \varepsilon$ \\
\hline Shock Suku PUAB ON & 124 & 248 & 496 \\
\hline Shock Indeks VIX & 198 & 396 & 791 \\
\hline
\end{tabular}

Langkah selanjutnya adalah melakukan simulasi berdasarkan shock keempat variabel tersebut sesuai kondisinya sehingga menghasilkan hasil simulasi sebagaimana pada Tabel 5 .

\begin{tabular}{|c|c|c|c|c|c|c|}
\hline \multicolumn{7}{|c|}{$\begin{array}{l}\text { Tabel } 5 . \\
\text { Pengaruh Shock } 4 \text { Variabel terhadap Posisi Net Transaksi Investor Asing (Miliar Rp) }\end{array}$} \\
\hline \multirow{2}{*}{ Investor } & \multicolumn{3}{|c|}{ Shock 1 Hari (Miliar Rp) } & \multicolumn{3}{|c|}{ Permanen Shock 1 Bulan (Miliar Rp) } \\
\hline & Mild & Moderate & Crisis & Mild & Moderate & Crisis \\
\hline LONG-TERM & -4.5 & -9.0 & -18.0 & -22.5 & -45.1 & -180.0 \\
\hline SHORT-TERM & -34.7 & -69.5 & -138.9 & -173.67 & -347.4 & $-1,390.1$ \\
\hline TOTAL & -39.2 & -78.5 & -157.0 & -196.2 & -392.5 & $-1,570.1$ \\
\hline
\end{tabular}

Berdasarkan tabel tersebut dapat diperoleh bahwa investor short-term lebih sensitif terhadap shock yang terjadi pada keempat variabel penjelas. Hal ini disebabkan karena keempat variabel penjelas tersebut dapat mempengaruhi secara signifikan keputusan investor short-term, sementara investor long-term hanya dipengaruhi oleh dua push factor yaitu US T Notes dan indeks VIX. Temuan ini juga mengkonfirmasi bahwa apabila terjadi shock yang menyebabkan berubahnya keempat variabel penjelas, maka investor short-term menjadi investor yang lebih bereaksi lebih cepat dalam merespon shock tersebut. Atau dengan kata lain, dalam hal terjadi shock maka pasar menjadi sangat berfluktuatif sebagai akibat dari respon investor short-term.

Dengan demikian di tengah kondisi pasar keuangan global yang masih rentan akibat dari tingginya ketidakpastian di kawasan Euro serta tingginya utang pemerintah AS maka ke depan prospek capital flows di pasar SUN masih menghadapi tantangan khususnya dalam hal merespon shock yang akan terjadi. Tingginya pengaruh faktor global di pasar SUN akan menyebabkan tingginya volatilitas yang terjadi di pasar SUN apabila terjadi shock di pasar keuangan global. Investor asing khususnya investor short-term akan merespon shock tersebut dengan melakukan penjualan sehingga diperkirakan akan dapat mengganggu kestabilan pasar keuangan secara keseluruhan maupun kestabilan di pasar valas yang pada akhirnya dapat mempengaruhi kestabilan nilai tukar. 


\section{KESIMPULAN}

Paper ini memberikan beberapa kesimpulan, pertama, investor asing di pasar SUN sangat dipengaruhi oleh faktor risiko global (push factors). Dipasar SUN yang memiliki komposisi investor long-term dan short-term yang relatif sama (46:34) menunjukkan bahwa push factor yang tercermin dari rendahnya yield US T Notes 5 tahun dan global risk appetite (indikator VIX) sangat berperan dalam keputusan investasi mereka. Hal ini menunjukkan bahwa apabila sewaktu-waktu terjadi shock di pasar keuangan global, antara lain akibat krisis keuangan di Eropa maka investor asing akan merespon shock tersebut dengan melakukan penjualan massal (massive selling) sehingga berpotensi untuk dapat mengganggu kestabilan di pasar keuangan dalam negeri dan nilai tukar. Kedua, selain push factor, perilaku investor short-term juga dipengaruhi oleh pull factor (faktor return dan risiko domestik), yang masing-masing dicerminkan oleh yield SUN 5 tahun dan suku bunga PUAB ON. Peningkatan yield SUN akan tetap mendorong aliran modal asing masuk ke pasar SUN. Sebaliknya peningkatan suku bunga PUAB ON akan berdampak pada penurunan aliran modal asing yang masuk ke pasar SUN. Banyaknya variabel yang mempengaruhi transaksi investor short-term berimplikasi pada semakin reaktifnya respon investor short-term dalam menghadapi shock yang terjadi, dibandingkan investor long-term. Ketiga, hasil simulasi menunjukkan bahwa prospek investor asing di pasar SUN ke depan masih menghadapi tantangan khususnya di tengah kondisi pasar keuangan global yang masih rentan terhadap ketidakpastian. Kuatnya pengaruh push factor terhadap transaksi investor asing menunjukkan bahwa pasar SUN masih akan menghadapi tingkat volatilitas yang relatif tinggi sebagai akibat dari respon investor asing khususnya investor short-term dalam menghadapi shock yang akan terjadi.

Kesimpulan di atas membawa konsekuensi kebijakan, pertama, Bank Indonesia dan Pemerintah perlu terus mempertahankan upaya untuk menjaga dan mengelola return dan risiko investasi di dalam negeri pada level yang kompetitif dan relatif rendah serta menjaga kekuatan dan ketangguhan perekonomian domestik agar investor asing dapat tetap menempatkan investasinya di pasar keuangan domestik. Beberapa hal yang perlu dilakukan Bank Indonesia adalah dengan menjaga stabilitas pasar keuangan domestik. Kedua, Bank Indonesia dan Pemerintah perlu bekerja sama dalam membentuk suatu contingency plan untuk menjaga stabilitas di pasar SUN apabila sewaktu-waktu terjadi volatilitas yang berlebihan yang disebabkan respon investor asing khususnya sebagai akibat dari memburuknya kondisi pasar keuangan global. 


\section{DAFTAR PUSTAKA}

Campbel JY and LM Viceira (2001). "Strategic Assets Allocation: Portfolio Choice for Long-term Investors," http://ciber.fuqua.duke.edu/ charvey/Teaching/BA453 2006/Campbell Viceira. pdf.

Chuhan, P, S. Claessens and N. Mamingi (1993). "Equity and Bond Flows to Asia and Latin America; The Role of Global and Country Factors," Policy Research, Working Papers, WPS 1160.

Culha, Ali Askin (2006), "A Structural VAR Analysis of the Determination of Capital Flow into Turkey," Central Bank Review, Central Bank of the Republic of Turkey.

Cuthbertson, K and D. Nitzsche (2005), "Quantitative Financial Economics: Stocks, Bonds and Foreign Exchange," John Wiley and Sons, Ltd, Second Edition.

Forbes, KJ. andFE. Warnock (2011). "Capital Flow Waves: Surges, Stops, Flight, and Retrenchment," National Bureau of Economic Research, Working Paper 17351, August 2011.

Fratzscher, Marcel (2011). "Capital Flows, Push Versul Pull factors and the Global Financial Crisis," National Bureau of Economic Research, Working Paper 17357, August 2011.

Goldfajn, Ilan and A. Minella (2005), "Capital Flows and Controls in Brazil: What have we learned?", National Bureau of Economic Research, Working Paper 11640, September 2005.

Gyntelberg J, M. Loretan, T. Subhani, and E. Chan (2009) "International portfolio rebalancing and exchange rate fuctuations in Thailand," BIS Working Papers No. 287.

Kaminsky, G. and S. Schumukler (2002), "Emerging market Instability: Do Sovereign Ratings Affect Country Risk and Stock Returns?" The World Bank Economic Review, Vol. 16, No. 2, pp 171-195.

Miller, NC and N. Whitman (1970). "A Mean-Variance Analysis of United States Long-term Portfolio Foreign Investment," The Quarterly Journal of Economics, Vol. 84, No. 2 (May, 1970), pp. 175-196

Ostry, JD et al (2011), "Managing Capital Inflows: What Tools to Use? IMF Staff Discussion Note, April 2011. 
IMF (2011), "Recent Experiences in Managing Capital Inflows-Cross-Cutting Themes and Possible Policy Framework," Prepared by the Strategy, Policy, and Review Department.

Vita, Glauco De and KS Kyaw (2007). "Determinants of Capital Flows to Developing Countries: A Structural VAR Analysis," Journal of Economic Studies, Vol. 35 No. 4. 2008, pp 304-322.

Ying, YH. and Y. Kim (2001). "An Empirical Analysis on Capital Flows: the Case of Korea and Mexico," Southern Economic Journal, April 2001; 67, 954-967.

Agung, Juda., Nugroho, M.N., Yanfitri. 2011. "Arus Modal Jangaka Pendek di Indonesia Pasca Krisis Global: Karakteristik, Prosepek, dan Respon Kebijakan". Working Paper Bank Indonesia.

Akitoby, B. dan T. Stratmann, 2006, "Fiscal policy and Financial Markets", IMF.

Boot, A. et al., 2005, "Credit Rating as Coordination Mechanism", Oxfords University Press. Cantor, R. dan F. Packer, 1996, "Determinants and Impact of Sovereign Credit Rating". FRBNY Economic policy Review/October 1996.

Cavallo, E., et al., 2008. "Do Credit Rating Agencies Add value? Evidence from the Sovereign Rating Business. Inter-American Development Bank.Edwards, S., 1985. "The Pricing of Bonds and Bank Loans in International Markets: An Empirical Analysis of Developing Countries' Foreign Borrowing", National Bureau of Economic Research.

Hartilius, K., K. Kashiwase. and L/E. Kodres (2008), "Emerging marketspread Compressions: Is it Real or is it Liquidity? IMF Working Paper 08/10

Jaramillo, L. dan C.M. Tejada, 2011, "Sovereign Credit Ratings and Spread in Emerging market: Does Investment grade Matter?", IMF.

Jeramillo, L., 2010, "Determinants of Investment grade Status in Emerging market", IMF.

Kaminsky, G. dan S. Schmukler, 2001. "Emerging markets Instability: Do Sovereign Rating Affect Country Risk and Stock Return?", World Bank.

Kiff, J. et al., 2012. "Are Rating Agencies Powerful? An Investigation into the Impact and Accuracy of Sovereign Ratings". IMF.

Lee, K., et al. , 2010. "Sovereign debt Rating Changes and Stock Liquidity around the World", Korea University Business School.

Powel, A. dan J.F. Martinez, 2008, "On Emerging Economy SovereignSpreads and Rating". Inter-American Development Bank.

Rozada, M. G. dan E.L.Yeyati, 2011, "Risk Appetite and Emerging marketSpreads". Universidad Torcuato Di Tella.

Rozada, M.G., 2005, "Global Factors and Emerging marketSpreads", Universidad Torcuato Di Tella. 


\section{LAMPIRAN}

Dependent Variable: POSNET

Method: ML - ARCH

Date: 08/07/12 Time: 12:06

Sample (adjusted): 31589

Included observations: 1587 after adjustments

Convergence achieved after 200 iterations

Presample variance: backcast $($ parameter $=0.7)$

$\mathrm{GARCH}=\mathrm{C}(8)+\mathrm{C}(9)^{*} \mathrm{RESID}(-1)^{\wedge} 2+\mathrm{C}(10)^{*} \mathrm{GARCH}(-1)$

\begin{tabular}{|c|c|c|c|c|}
\hline Variable & Coefficient & Std. Error & z-Statistic & Prob. \\
\hline C & 113.9447 & 25.58712 & 4.453207 & 0.0000 \\
\hline POSNET(-1) & 1.225203 & 0.020526 & 59.68938 & 0.0000 \\
\hline POSNET(-2) & -0.224816 & 0.020606 & 10.91041 & 0.0000 \\
\hline YIELD5 & -1.879022 & 2.237839 & -0.839659 & 0.4011 \\
\hline UST5 & -11.34816 & 5.689463 & -1.994592 & 0.0461 \\
\hline PUAB & 1.084902 & 1.497364 & 0.724541 & 0.4687 \\
\hline VIX & -1.846067 & 0.447188 & -4.128165 & 0.0000 \\
\hline \multicolumn{5}{|c|}{ Variance Equation } \\
\hline C & 112.1908 & 26.54838 & 4.225898 & 0.0000 \\
\hline $\operatorname{RESID}(-1)^{\wedge} 2$ & 0.065630 & 0.004167 & 15.74970 & 0.0000 \\
\hline GARCH(-1) & 0.942322 & 0.003231 & 291.6428 & 0.0000 \\
\hline R-squared & 0.999948 & Mean dependent var & & 34420.70 \\
\hline Adjusted R-squared & 0.999948 & S.D. dependent var & & 31564.77 \\
\hline S.E. of regression & 227.7380 & Akaike info criterion & & 13.30994 \\
\hline Sum squared resid & 81946030 & Schwarz criterion & & 13.34377 \\
\hline Log likelihood & -10551.44 & Hannan-Quinn criter. & & 13.32251 \\
\hline Durbin-Watson stat & 2.100886 & & & \\
\hline
\end{tabular}


Dependent Variable: POSNET

Method: ML - ARCH

Date: 08/07/12 Time: 12:38

Sample (adjusted): 171945

Included observations: 1929 after adjustments

Convergence achieved after 182 iterations

Presample variance: backcast (parameter $=0.7$ )

$\mathrm{GARCH}=\mathrm{C}(8)+\mathrm{C}(9)^{\star} \operatorname{RESID}(-1)^{\wedge} 2+\mathrm{C}(10)^{\star} \mathrm{GARCH}(-1)$

\begin{tabular}{|c|c|c|c|c|}
\hline Variable & Coefficient & Std. Error & z-Statistic & Prob. \\
\hline C & 267.7758 & 63.92264 & 4.189061 & 0.0000 \\
\hline POSNET(-1) & 1.181177 & 0.021589 & 54.71125 & 0.0000 \\
\hline POSNET(-2) & -0.181296 & 0.021475 & -8.442287 & 0.0000 \\
\hline YIELD5 & 25.49576 & 7.244728 & 3.519216 & 0.0004 \\
\hline UST5 & -80.70680 & 15.62070 & -5.166659 & 0.0000 \\
\hline PUAB & -11.06977 & 5.938876 & -1.863951 & 0.0623 \\
\hline VIX & -7.074447 & 1.445532 & -4.894009 & 0.0000 \\
\hline \multicolumn{5}{|c|}{ Variance Equation } \\
\hline C & 2712.545 & 357.6632 & 7.584077 & 0.0000 \\
\hline $\operatorname{RESID}(-1)^{\wedge} 2$ & 0.045191 & 0.004001 & 11.29609 & 0.0000 \\
\hline GARCH(-1) & 0.946503 & 0.003923 & 241.2823 & 0.0000 \\
\hline R-squared & 0.999249 & Meandependentvar & & 40883.19 \\
\hline Adjusted R-squared & 0.999246 & S.D. dependent var & & 17901.91 \\
\hline S.E. of regression & 491.4292 & Akaike info criterion & & 15.10255 \\
\hline Sum squared resid & $4.64 \mathrm{E}+08$ & Schwarz criterion & & 15.13139 \\
\hline Log likelihood & -14556.41 & Hannan-Quinn criter. & & 15.11316 \\
\hline Durbin-Watson stat & 2.023039 & & & \\
\hline
\end{tabular}


Dependent Variable: POSNET_A

Method: $M L$ - ARCH

Date: 08/03/12 Time: 15:17

Sample (adjusted): 31515

Included observations: 1513 after adjustments

Convergence achieved after 344 iterations

Presample variance: backcast (parameter $=0.7$ )

$\mathrm{GARCH}=\mathrm{C}(8)+\mathrm{C}(9)^{*} \mathrm{RESID}(-1)^{\wedge} 2+\mathrm{C}(10)^{\star} \mathrm{GARCH}(-1)$

\begin{tabular}{|c|c|c|c|c|}
\hline Variable & Coefficient & Std. Error & z-Statistic & Prob. \\
\hline C & 159.9976 & 53.96929 & 2.964604 & 0.0030 \\
\hline POSNET_A(-1) & 1.117612 & 0.021647 & 51.62911 & 0.0000 \\
\hline POSNET_A(-2) & -0.118524 & 0.021635 & -5.478300 & 0.0000 \\
\hline YIELD5 & -2.332061 & 3.515187 & -0.663424 & 0.5071 \\
\hline UST5 & -18.73924 & 7.558758 & -2.479143 & 0.0132 \\
\hline PUAB & 1.918756 & 1.580038 & 1.214373 & 0.2246 \\
\hline VIX & -2.083042 & 0.623298 & -3.341967 & 0.0008 \\
\hline \multicolumn{5}{|c|}{ Variance Equation } \\
\hline C & 57.43522 & 8.271893 & 6.943419 & 0.0000 \\
\hline $\operatorname{RESID}(-1)^{\wedge} 2$ & 0.012574 & 0.000940 & 13.37871 & 0.0000 \\
\hline GARCH(-1) & 0.987983 & 0.000872 & 1132.507 & 0.0000 \\
\hline R-squared & 0.999852 & Mean dependent var & & 23836.44 \\
\hline Adjusted R-squared & 0.999851 & S.D. dependent var & & 17590.30 \\
\hline S.E. of regression & 214.6835 & Akaike info criterion & & 13.31744 \\
\hline Sum squared resid & 69410069 & Schwarz criterion & & 13.35262 \\
\hline Log likelihood & -10064.65 & Hannan-Quinn criter. & & 13.33054 \\
\hline Durbin-Watson stat & 2.026375 & & & \\
\hline
\end{tabular}


Dependent Variable: POSNET_B

Method: ML - ARCH

Date: 08/03/12 Time: 15:04

Sample (adjusted): 3723

Included observations: 721 after adjustments

Convergence achieved after 465 iterations

Presample variance: backcast (parameter $=0.7$ )

$\mathrm{GARCH}=\mathrm{C}(8)+\mathrm{C}(9)^{*} \mathrm{RESID}(-1)^{\wedge} 2+\mathrm{C}(10)^{*} \mathrm{GARCH}(-1)$

\begin{tabular}{|c|c|c|c|c|}
\hline Variable & Coefficient & Std. Error & z-Statistic & Prob. \\
\hline C & 54.51141 & 28.97710 & 1.881190 & 0.0599 \\
\hline POSNET_B(-1) & 1.176329 & 0.051550 & 22.81920 & 0.0000 \\
\hline POSNET_B(-2) & -0.175697 & 0.051447 & -3.415099 & 0.0006 \\
\hline YIELD5 & 3.520425 & 5.493664 & 0.640816 & 0.5216 \\
\hline UST5 & -16.72747 & 9.758567 & -1.714132 & 0.0865 \\
\hline PUAB & 3.709431 & 5.914948 & 0.627128 & 0.5306 \\
\hline VIX & -2.164078 & 0.527622 & -4.101572 & 0.0000 \\
\hline \multicolumn{5}{|c|}{ Variance Equation } \\
\hline C & 181.0126 & 33.29521 & 5.436596 & 0.0000 \\
\hline $\operatorname{RESID}(-1)^{\wedge} 2$ & 0.061301 & 0.006666 & 9.195631 & 0.0000 \\
\hline GARCH(-1) & 0.928537 & 0.009601 & 96.71625 & 0.0000 \\
\hline R-squared & 0.999740 & Mean dependent var & & 6627.379 \\
\hline Adjusted R-squared & 0.999737 & S.D. dependent var & & 5441.296 \\
\hline S.E. of regression & 88.17261 & Akaike info criterion & & 11.72626 \\
\hline Sum squared resid & 5550928. & Schwarz criterion & & 11.78980 \\
\hline Log likelihood & -4217.318 & Hannan-Quinn criter. & & 11.75079 \\
\hline Durbin-Watson stat & 2.168429 & & & \\
\hline
\end{tabular}


Dependent Variable: POSNET_C

Method: ML - ARCH

Date: 08/03/12 Time: 14:10

Sample (adjusted): 3611

Included observations: 609 after adjustments

Failure to improve Likelihood after 213 iterations

Presample variance: backcast $($ parameter $=0.7)$

$\mathrm{GARCH}=\mathrm{C}(8)+\mathrm{C}(9)^{*} \mathrm{RESID}(-1)^{\wedge} 2+\mathrm{C}(10)^{*} \mathrm{GARCH}(-1)$

\begin{tabular}{|c|c|c|c|c|}
\hline Variable & Coefficient & Std. Error & z-Statistic & Prob. \\
\hline C & 12.55903 & 7.383175 & 1.701034 & 0.0889 \\
\hline POSNET_C(-1) & 1.347741 & 0.063468 & 21.23494 & 0.0000 \\
\hline POSNET_C(-2) & -0.345492 & 0.063317 & -5.456547 & 0.0000 \\
\hline YIELD5 & -0.737508 & 0.854343 & -0.863246 & 0.3880 \\
\hline UST5 & -0.495133 & 1.280885 & -0.386556 & 0.6991 \\
\hline PUAB & -0.466432 & 0.454711 & -1.025777 & 0.3050 \\
\hline VIX & 0.144641 & 0.222908 & 0.648883 & 0.5164 \\
\hline \multicolumn{5}{|c|}{ Variance Equation } \\
\hline C & 2.677693 & 3.106823 & 0.861875 & 0.3888 \\
\hline $\operatorname{RESID}(-1)^{\wedge} 2$ & 0.264474 & 0.035762 & 7.395345 & 0.0000 \\
\hline GARCH(-1) & 0.816807 & 0.019423 & 42.05455 & 0.0000 \\
\hline R-squared & 0.999886 & Mean dependent var & & 11325.22 \\
\hline Adjusted R-squared & 0.999885 & S.D. dependent var & & 11157.35 \\
\hline S.E. of regression & 119.6815 & Akaike info criterion & & 11.29132 \\
\hline Sum squared resid & 8622845. & Schwarz criterion & & 11.36377 \\
\hline Log likelihood & -3428.208 & Hannan-Quinn criter. & & 11.31950 \\
\hline Durbin-Watson stat & 1.868649 & & & \\
\hline
\end{tabular}


Dependent Variable: POSNET_D

Method: ML - ARCH

Date: 08/03/12 Time: 15:32

Sample (adjusted): 31688

Included observations: 1686 after adjustments

Convergence achieved after 342 iterations

Presample variance: backcast (parameter $=0.7$ )

$\mathrm{GARCH}=\mathrm{C}(8)+\mathrm{C}(9)^{*} \mathrm{RESID}(-1)^{\wedge} 2+\mathrm{C}(10)^{*} \mathrm{GARCH}(-1)$

\begin{tabular}{|c|c|c|c|c|}
\hline Variable & Coefficient & Std. Error & z-Statistic & Prob. \\
\hline C & 92.70394 & 23.56513 & 3.933945 & 0.0001 \\
\hline POSNET_D(-1) & 1.063743 & 0.026182 & 40.62836 & 0.0000 \\
\hline POSNET_D(-2) & -0.067759 & 0.026147 & -2.591516 & 0.0096 \\
\hline YIELD5 & 3.319171 & 2.214957 & 1.498526 & 0.1340 \\
\hline UST5 & -12.14377 & 4.811679 & -2.523812 & 0.0116 \\
\hline PUAB & 0.700817 & 1.475683 & 0.474910 & 0.6349 \\
\hline VIX & -1.671124 & 0.591787 & -2.823863 & 0.0047 \\
\hline \multicolumn{5}{|c|}{ Variance Equation } \\
\hline C & 54.08519 & 10.04509 & 5.384244 & 0.0000 \\
\hline $\operatorname{RESID}(-1)^{\wedge} 2$ & 0.030750 & 0.001705 & 18.03498 & 0.0000 \\
\hline GARCH(-1) & 0.972435 & 0.001556 & 625.1126 & 0.0000 \\
\hline R-squared & 0.995748 & Mean dependent var & & 11222.39 \\
\hline Adjusted R-squared & 0.995733 & S.D. dependent var & & 2777.218 \\
\hline S.E. of regression & 181.4111 & Akaike info criterion & & 12.91675 \\
\hline Sum squared resid & 55255876 & Schwarz criterion & & 12.94896 \\
\hline Log likelihood & -10878.82 & Hannan-Quinn criter. & & 12.92868 \\
\hline Durbin-Watson stat & 2.029965 & & & \\
\hline
\end{tabular}


Dependent Variable: POSNET_E

Method: $M L$ - ARCH

Date: 08/03/12 Time: 15:38

Sample (adjusted): 31679

Included observations: 1677 after adjustments

Convergence achieved after 98 iterations

Presample variance: backcast (parameter $=0.7$ )

$\mathrm{GARCH}=\mathrm{C}(8)+\mathrm{C}(9)^{\star} \mathrm{RESID}(-1)^{\wedge} 2+\mathrm{C}(10)^{*} \mathrm{GARCH}(-1)$

\begin{tabular}{|c|c|c|c|c|}
\hline Variable & Coefficient & Std. Error & z-Statistic & Prob. \\
\hline C & 189.2419 & 36.57877 & 5.173546 & 0.0000 \\
\hline POSNET_E(-1) & 1.077573 & 0.024414 & 44.13708 & 0.0000 \\
\hline POSNET_E(-2) & -0.077229 & 0.024344 & -3.172443 & 0.0015 \\
\hline YIELD5 & 5.491383 & 4.269940 & 1.286056 & 0.1984 \\
\hline UST5 & -37.09031 & 9.909066 & -3.743069 & 0.0002 \\
\hline PUAB & -5.283109 & 3.799146 & -1.390604 & 0.1643 \\
\hline VIX & -3.488436 & 0.945942 & -3.687791 & 0.0002 \\
\hline \multicolumn{5}{|c|}{ Variance Equation } \\
\hline C & 783.2013 & 150.2073 & 5.214138 & 0.0000 \\
\hline $\operatorname{RESID}(-1)^{\wedge} 2$ & 0.036261 & 0.004220 & 8.592922 & 0.0000 \\
\hline GARCH(-1) & 0.955605 & 0.005294 & 180.5000 & 0.0000 \\
\hline R-squared & 0.998968 & Mean dependent var & & 8069.767 \\
\hline Adjusted R-squared & 0.998964 & S.D. dependent var & & 9175.607 \\
\hline S.E. of regression & 295.2718 & Akaike info criterion & & 14.04298 \\
\hline Sum squared resid & $1.46 \mathrm{E}+08$ & Schwarz criterion & & 14.07532 \\
\hline Log likelihood & -11765.03 & Hannan-Quinn criter. & & 14.05496 \\
\hline Durbin-Watson stat & 1.989021 & & & \\
\hline
\end{tabular}


Dependent Variable: POSNET_F

Method: ML - ARCH

Date: 08/03/12 Time: $15: 48$

Sample (adjusted): 31688

Included observations: 1686 after adjustments

Convergence achieved after 125 iterations

Presample variance: backcast (parameter $=0.7$ )

$\mathrm{GARCH}=\mathrm{C}(8)+\mathrm{C}(9)^{*} \operatorname{RESID}(-1)^{\wedge} 2+\mathrm{C}(10)^{*} \mathrm{GARCH}(-1)$

\begin{tabular}{|c|c|c|c|c|}
\hline Variable & Coefficient & Std. Error & z-Statistic & Prob. \\
\hline C & 96.93787 & 29.00713 & 3.341864 & 0.0008 \\
\hline POSNET_F(-1) & 1.034479 & 0.034218 & 30.23195 & 0.0000 \\
\hline POSNET_F(-2) & -0.037215 & 0.034256 & -1.086378 & 0.2773 \\
\hline YIELD5 & 8.528477 & 3.021516 & 2.822582 & 0.0048 \\
\hline UST5 & -14.31859 & 5.995188 & -2.388347 & 0.0169 \\
\hline PUAB & -7.352710 & 1.898121 & -3.873678 & 0.0001 \\
\hline VIX & -1.556119 & 0.650834 & -2.390961 & 0.0168 \\
\hline \multicolumn{5}{|c|}{ Variance Equation } \\
\hline C & 5936.775 & 549.5556 & 10.80287 & 0.0000 \\
\hline $\operatorname{RESID}(-1)^{\wedge} 2$ & 0.103559 & 0.010013 & 10.34206 & 0.0000 \\
\hline $\mathrm{GARCH}(-1)$ & 0.710128 & 0.024614 & 28.85108 & 0.0000 \\
\hline R-squared & 0.997706 & Mean dependent var & & 15001.01 \\
\hline Adjusted R-squared & 0.997698 & S.D. dependent var & & 3688.146 \\
\hline S.E. of regression & 176.9552 & Akaike info criterion & & 13.12920 \\
\hline Sum squared resid & 52574769 & Schwarz criterion & & 13.16141 \\
\hline Log likelihood & -11057.92 & Hannan-Quinn criter. & & 13.14113 \\
\hline Durbin-Watson stat & 2.007265 & & & \\
\hline
\end{tabular}


Dependent Variable: POSNET_G

Method: ML - ARCH

Date: 08/03/12 Time: 15:53

Sample (adjusted): 31670

Included observations: 1668 after adjustments

Convergence not achieved after 500 iterations

Presample variance: backcast (parameter $=0.7$ )

$\mathrm{GARCH}=\mathrm{C}(8)+\mathrm{C}(9)^{*} \mathrm{RESID}(-1)^{\wedge} 2+\mathrm{C}(10)^{*} \mathrm{GARCH}(-1)$

\begin{tabular}{|c|c|c|c|c|}
\hline Variable & Coefficient & Std. Error & z-Statistic & Prob. \\
\hline C & 113.0265 & 24.90232 & 4.538795 & 0.0000 \\
\hline POSNET_G(-1) & 0.966284 & 0.024542 & 39.37210 & 0.0000 \\
\hline POSNET_G (-2) & 0.023345 & 0.024728 & 0.944049 & 0.3451 \\
\hline YIELD5 & 12.25185 & 2.539103 & 4.825268 & 0.0000 \\
\hline UST5 & -20.93090 & 5.175821 & -4.043977 & 0.0001 \\
\hline PUAB & -0.492255 & 1.616411 & -0.304536 & 0.7607 \\
\hline VIX & -3.173168 & 0.512478 & -6.191808 & 0.0000 \\
\hline \multicolumn{5}{|c|}{ Variance Equation } \\
\hline C & 18657.47 & 421.8118 & 44.23174 & 0.0000 \\
\hline $\operatorname{RESID}(-1)^{\wedge} 2$ & 0.817660 & 0.052944 & 15.44399 & 0.0000 \\
\hline GARCH(-1) & 0.018109 & 0.011761 & 1.539728 & 0.1236 \\
\hline R-squared & 0.995271 & Mean dependent var & & 9755.743 \\
\hline Adjusted R-squared & 0.995254 & S.D. dependent var & & 2669.271 \\
\hline S.E. of regression & 183.8912 & Akaike info criterion & & 13.07786 \\
\hline Sum squared resid & 56168322 & Schwarz criterion & 13.11035 & \\
\hline Log likelihood & -10896.93 & Hannan-Quinn criter. & & 13.08990 \\
\hline Durbin-Watson stat & 1.963220 & & & \\
\hline
\end{tabular}

